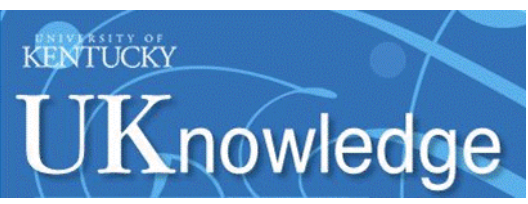

Kentucky Law Journal

2008

\title{
Was It Good for You Too? Conversation Analysis of Two Interviews
}

Linda F. Smith

University of Utah

Follow this and additional works at: https://uknowledge.uky.edu/klj

Part of the Legal Profession Commons

Right click to open a feedback form in a new tab to let us know how this document benefits you.

\section{Recommended Citation}

Smith, Linda F. (2008) "Was It Good for You Too? Conversation Analysis of Two Interviews," Kentucky Law Journal: Vol. 96: Iss. 4, Article 4.

Available at: https://uknowledge.uky.edu/klj/vol96/iss4/4

This Article is brought to you for free and open access by the Law Journals at UKnowledge. It has been accepted for inclusion in Kentucky Law Journal by an authorized editor of UKnowledge. For more information, please contact UKnowledge@lsv.uky.edu. 


\title{
Was It Good for You Too? Conversation Analysis of Two Interviews
}

\author{
Linda F. Smith'
}

\begin{abstract}
Because an attorney-client interview is a conversation between two people, conversation analysis can be useful in assessing the effectiveness of an interview. Clients, as well as lawyers have intentions and goals regarding that meeting which, together with their conversational styles, help shape the interview and contribute to its success (or failure). The lawyer is not solely in charge. This article analyzes two interviews by two attorneys, each with an extemporaneous actor playing the same client role. The substantial transcript excerpts are analyzed to illustrate some of what we know about good interviewing and to call into question other lessons we teach.
\end{abstract}

T Aw professors have been teaching law students how to interview clients for at least three decades. ${ }^{2}$ Today there is substantial agreement amongst these teachers about what constitutes a good interview. All texts recommend that clients be permitted to describe the situation in their own words and to give a narrative or time line. ${ }^{3}$ They caution the attorney to listen, to avoid interrupting the client ${ }^{4}$ and to engage in "active listening"

1 Professor and Clinical Program Director, University of Utah S. J. Quinney College of Law. I am very grateful for the helpful comments on earlier drafts from Clark Cunningham, James Holbrook, Paul Maharg, and Paul Tremblay and for the College of Law Faculty Development Fund which supported this research.

2 See David A. Binder \& Susan C. Price, Legal Interviewing and Counseling: A Client-Centered Approach (1977) [hereinafter Binder et al., Legal Interviewing and Counseling]; Gary Bellow \& Bea Moulton, The lawyering Process: Materials for Clinical Instruction In Advocacy (1978).

3 David Binder, Paul Bergman, Susan Price \& Paul Tremblay, Lawyers as Counselors: A Client CenTERED APPROACH 87, I 2 (2004) (suggesting beginning with "preliminary problem identification" followed by a "time line" of the events giving rise to the problem) [hereinafter Binder et al., Lawyers as Counselors]; Robert Cochran, John DiPippa \& Martha Peters, The Counselor-at-Law: A Collaborative Approach to Client Interviewing and Counseling 73 (2nd ed., 2006) (recommending that the attorney "hears the client's story in the client's own words"); Stefan Kreiger \& Richard Neumann, Essential Lawyering Skills 85 (2003) (recommending the information gathering begin with "an open-ended narration stage (the client tells the story)").

4 BiNDER ET AL., supra, note 3, at 100 (warning against interrupting even emotional and convoluted responses at the outset of an interview.); CoCHRAN ET AL., supra, note 3, at 8690 (relying upon studies of medical and legal interviews to caution against interruptions); KREIGER ET AL, supra note 3 , at $4 \mathrm{I}$ and 87 (advocating more listening and cautioning against leaping in with questions at the beginning of the interview). 
or otherwise show empathy. ${ }^{5}$ After the narrative or time line the attorney should question the client about relevant topics. ${ }^{6}$ The questioning should be organized and certain question forms are recommended. ${ }^{7}$ Interviews should conclude in an orderly way with plans for the future and possibly an assessment of the client's situation. ${ }^{8}$

Although there is substantial agreement about interviewing techniques, how do we know that any of this guidance is sound? Where the experts differ, do we know which expert is right? How do we know what is the most important lesson? And which instructions about interviewing are appropriate for the law school novice and which appropriate only for the lawyer with substantial expertise in a practice area?

In fact much (most?) of our instruction regarding interview techniques is based on theory alone. Very little of what we teach is based on research. Some of the research we rely upon is borrowed from studies of other professions, since there are only a handful of studies about lawyer-client interviews.

This study adds to the slowly growing body of empirical work regarding attorney-client interviews. It first introduces conversation analysis as a useful approach to learn about interviewing and then applies conversation analysis to compare and contrast two very different interview performances in the same case. In the course of the analysis of data and of the transcripts themselves, this article will both confirm and call into question various lessons we teach about client interviewing and propose certain principles about what makes for a good interview and why.

5 Binder et al., Lawyers as Counselors, supta note 3 , at $41-63$ (discussing active listening); CochraN ET AL., supra note 3, at 35-45 (discussing mirroring and reflective statements); KREIGER ET AL., supra note 3, at 39-57 (recommending listening with empathy).

6 See Binder et al., Lawyers as Counselors, supra note 3, at 149-92 (discussing "theory development questioning,"); CoCHRAN ET AL., supra note 3 at 95 (advocating "clarifying and exploring the client's story"); KREIGER ET AL., supra note 3, at 75 (discussing the "probing stage").

7 Binder advises the interviewer to follow the time line or narrative with "T-funnel" questioning by beginning with "open" questions and proceeding to more narrow and closed questioning. Binder et Al., Lawyers as Counselors, supra note 3, at 167, 64-77; Cochran warns against asking too many questions so "the client is 'taught' that the lawyer is in control of the interview" and recommends open questions when "undertaking a new line of inquiry." Cochran et AL., supra note 3, at 48, 53; Krieger advises interviewers to "take up each topic separately" and "on each topic, start with broad questions ... and gradually work your way toward narrow ones." KRIEGER ET AL., supra note 3 at 98.

8 Binder et AL., LAWYers as CoUnselors, supra note 3, at 234-46 (proposing specifying the next steps, formalizing the relationship and giving a tentative assessment); CoCHRAN ET AL., supra note 3, at $103-06$ (recognizing that sometimes the attorney and client can immediately move to the counseling stage, but minimally they should formalize their relationship and mutual responsibilities going forward); KREIGER ET AL., supra note 3, at 93, 104 (recommending formalizing the relationship and outlining the next steps, but warn against a premature prediction). 


\section{Background-The Study with Extemporaneous Actors \& Lawyers}

To teach our law students how to interview a client, at the University of Utah we have been using actors trained in extemporaneous acting to play clients from actual closed cases. The actors are told the facts at the time the real client approached the lawyer-both what happened and the context of their legal issue. They are informed of their feelings and goals. The actors are asked to behave as they would if this was their legal problem and they were seeing a lawyer for an initial interview.

The actors are not told how the law student is supposed to behave or what skills we are trying to instill in the law student. They are not given a set of bench marks to use to assess the student's performance. ${ }^{9}$ At the conclusion of the interview, the actor is invited to give the law student feedback purely from the "how it felt to me" perspective of a lay person. The interview and the feedback are filmed and the actor completes a short written feedback form as well. (The actor's perspective is infrequently relied upon in grading the student's performance).

While there are no doubt disadvantages to using this approach-the actors generally appear to be of above average intelligence and verbal ability and may have an above average propensity to express emotion-the use of extemporaneous actors has other clear advantages in teaching, and more importantly here, in studying client interviewing. Because the "clients" have been trained in extemporaneous acting, they do not learn a script but independently decide how to present themselves. One significant advantage with this is that the same situation may be portrayed by different individuals differently, allowing us to see both the variation as well as the commonalities in approaches taken by the actor-clients. Likewise, the same actor can be interviewed by more than one student to see how much the actor-client varies his approach in response to what the student lawyer does. ${ }^{10}$ Finally, asking actors to assume this role and then provide critique to the student provides data from the untutored lay person's experience.

Do all uninstructed actors agree about certain techniques or is there variation about what different actor-clients prefer? This data can also be compared with the judgment of the professor teaching and assessing

9 This is in contrast to the "standardized patient" used in medical education and the "standardized client" approach in which the lay person is trained to give feedback on the behaviors that have been identified as desirable in an interview. See Karen Barton, Clark D. Cunningham, Gregory Todd Jones \& Paul Maharg, Valuing What Clients Think: Standardized Clients and the Assessment of Communicative Competence, 13 Clinical L. REv. I, 3 (2006); David Stern, Outside the Classroom: Teaching and Evaluating Future Physicians, 20 GA. ST. U. L. Rev. 877, 893-94 (2004); further discussion, infra, regarding the empirical work upon which this is based.

Io I am currently working on a new paper that explores both these issues--similarities/ differences among four male actor-clients and similarities/differences of an actor-client with different law student interviewers. 
the student's performance to see whether the untrained actor-clients' reactions to interviews are consistent with or different from the judgment of law faculty who try to teach these elusive skills. Where the actors' and professors' judgments are in conflict, it should cause us to reflect, to address this issue in our research and teaching, and possibly to reconsider our standards. Where there is high correlation between the actors' and the professors' assessment, it should inspire us to closely analyze what is occurring that leads to success. ${ }^{11}$

Of course, all the students have been instructed and are attempting to conduct an interview (for a grade) in accordance with their understanding of that instruction. One semester-in addition to having various actor-clients be interviewed by law students-I included five experienced lawyers in the pool. These lawyers were not instructed in how we expected them to conduct an interview, but simply asked to conduct the interview as part of our study. Although the actor-clients may have guessed, based on age or attire, that some individuals were lawyers, we treated the lawyers and law students alike in conducting this experiment. None of these lawyers had expertise in the area of law presented by the problem. So while they were experienced practitioners, they had no expertise in the applicable law. The thought was that their performance would present the most we could expect of law students or novice lawyers who, similarly, have no expertise in an area of law.

The case involved an employment dispute. Three lawyers interviewed the disgruntled employee and two lawyers interviewed a representative of the employer, a small business. All interviews were transcribed and subjected to basic coding by linguistics research assistants for conversation analysis. Of the five interviews, the two interviews of the employer presented the sharpest contrast. One lawyer (Attorney A) performed very consistently with our instructions about good interviewing. He gave the client wide latitude to explain the situation and then conducted follow-up questioning in a calm and organized manner. The other lawyer (Attorney B) made many of the mistakes we warn our students about. He interrupted the client's narrative very early and tried to control the interview in ways that prevented rather than helped the client to present the situation. The first interview by Attorney A contained few interruptions and was dominated by the client's story; the interview by Attorney B was full of interruptions and dominated by the lawyer.

Interestingly, however, Attorney A's male client (Vic) did not assess his performance as favorably as did Attorney B's female client (Vicki)! Since both attorneys were men, does this difference have to do with the different genders of the clients and their speech styles and orientation toward professionals?

I I See Barton et al., supra note 9 , at $1-89$ (describing the approach of correlating scores of faculty and of standardized clients to determine essential behaviors in a good interview). 
I decided to compare these two most different of interviews of the same "client" in the same "case" and provide both description and evaluation. What techniques did Attorney A use and how well did they serve? Were there techniques that Attorney A did not use? Were these errors that should be corrected or choices that were justifiable? Was Attorney A's performance substantially superior to Attorney B's? If so, why? If Attorney A's interview was superior to Attorney B's interview, what explains the client Vicki's favorable opinion? How should teachers handle this variation?

\section{Social Scientific Analysis of INTERviews ${ }^{12}$}

\section{A. Praxis Literature \& Correlation Studies}

Study of professional-client relationships has included systematic analysis of recorded or transcribed professional-client conferences. There are over 7,000 titles considering the doctor-patient consultation, with some (the praxis literature) comparing what is said with other data such as patient compliance, outcome of treatment, or patient satisfaction surveys. ${ }^{13}$ In these studies the researcher assigns "a single functional meaning (e.g. information-giving, affective display) to each utterance and then ... [codes] utterances into functional categories so that they can be quantified." 14 Then these coded results are compared to the other data (e.g. surveys of patients, data about patient compliance with treatment) to discover what works in interviewing by seeing what interview behaviors correlate with high patient satisfaction or patient compliance. ${ }^{15}$ Based on these studies, medical education has developed as a model-the "patient-centered interview"-with a series of pre-determined phases. ${ }^{16}$ Using these findings, a "standardized patient" can be trained to assess a medical interview by

12 Substantial portions of this background information have been published in my recent article, Linda F. Smith, Client-Lawyer Talk: Lessons from Other Disciplines, 13 Clinical L. Rev. 505 (2006) [hereinafter Smith, Client-Lawoyer Talk].

13 Nancy Ainsworth-Vaughn, The Discourse of Medical Encounters, in THE Handbook of Discourse Analysis 453 (Deborah Schiffrin, Deborah Tannen \& Heidi Hamilton, eds., 2003).

14 Id. at 453 .

15 Suzanne Fleischman, Language and Medicine, in The Handbook of Discourse ANalysis 470 (Deborah Schiffrin, Deborah Tannen \& Heidi Hamilton, eds., 2003).

I6 Ainsworth-Vaughn, supra note 13 , at 455. See Robert C. Smith, Patient-Centered INTERVIEWING: AN Evidence-BASED METHOD 35-67 (2002) (presenting "five steps and 2 I substeps of the patient-centered process of integrated interviewing"); Robert Smith, et al., The Effectiveness of Intensive Training for Residents in Interviewing, in 128 ANNALS OF INTERNAL MED. I 1 8-26 (1998) (demonstrating that intensive training of residents in interview techniques produces better interviews). 
recording whether the student doctor did or did not engage in the target

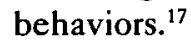

Only a little research of this sort has been done regarding legal interviews. In 2000 British professor Avram Sherr reported on his study of initial interviews in law offices in which the lawyers' self-assessments, clients' assessments and experts' assessments of videotaped performances were compared. ${ }^{18}$ Interestingly, the experts' assessment tended to find the lawyers "average" while the attorneys gave themselves relatively high rankings and the clients gave them even higher scores, with experience having little effect on the clients' or the experts' assessments. ${ }^{19}$

More recently, Clark Cunningham has spear-headed an ambitious research program, called the Effective Lawyer-Client Communication Project, which is designed to acquire similar raw data in the form of videotaped interviews and client surveys to study the effectiveness of initial attorney-client interviews. ${ }^{20}$ In a related endeavor, Cunningham and faculty from the Glasgow Graduate School of Law have developed a program to use standardized clients to test Scottish law graduates, having developed an assessment instrument in which faculty and trained standardized clients ranked eight qualities with a high degree of consistency. ${ }^{21}$

Obviously the legal world is far behind the world of medicine in researching effective interviewing in these ways. Moreover, the usefulness of this approach to study and judge interviewing relies upon the appropriateness of the standard (e.g. patient/client satisfaction) being correlated with certain behaviors and, when relying on expert assessment, upon the behaviors that are measured.

17 See Lawrence M. Grosberg, Medical Education Again Provides a Model for Lave Schools: The Standardized Patient Becomes the Standardized Client, 5 I J. LEGal ED. 2 I 2 (2001); Lawrence M. Grosberg, Standardized Clients: A Possible Improvement for the Bar Exam, $20 \mathrm{GA}$. Sr. U. L. Rev. 841 (2004); David Stern, Outside the Classroom: Teaching and Evaluating Future Physicians, 20 GA. ST. U. L. Rev. 877 (2004). See also Karen Barton, Clark D. Cunningham, Gregory Todd Jones \& Paul Maharg, Valuing What Clients Think: Standardized Clients and the Assessment of Communicative Competence, 13 J. CLINICAL ED. I (2006) for a discussion of the use of "standardized patients" in medical education and use of standardized clients in legal education.

18 Avrom Sherr, The Value of Experience in Legal Competence, 7 INTERNATIonal J. Legal Prof. 95 (2000).

I9 Id. at 105, 101-102, I12. The more experienced lawyers thought they did better than the less experienced lawyers thought they had done, but the experts and clients saw little difference.

20 The Effective Lawyer Client Communication Project has a website at: http://law. gsu.edu/Communication/ and this project has been discussed in Clark D. Cunningham, Evaluating Effective Lawyer-Client Communications: An International Project to Move from Research to Reform, 67 Fordham L. Rev. 1959 ( 1999).

2 I Barton, et al., supra note 9, at 42. 


\section{B. Conversation Analysis}

A second approach to analyzing professional-patient/client talk includes discourse, linguistic and conversation analysis, which focus on the talk itself. ${ }^{22}$ These approaches (also much more plentiful in medical studies than in legal research) often ask whether these professional encounters are conversation-like or like a structured interrogation. These analysts note that the patient can co-construct the discourse and alter what would otherwise have been the doctor's established structure for the encounter. ${ }^{23}$ They point out "the pitfalls in overt attempts to design the discourse of encounters without understanding the ways power is claimed through discourse." ${ }^{24}$ They urge that well-meaning instructors should not prescribe a structure for an interview without first understanding the structure in the conversations that are naturally occurring.

Discourse analysis is the study of "language in use" and involves systemic analysis of transcriptions of conversation. ${ }^{25}$ Conversational analysis contends that conversation partners actively create order through their interactive behavior ${ }^{26}$ These approaches to analyzing conversations often look to ordinary language philosophers who are concerned with the relationship between what is said and what the speaker intended. ${ }^{27}$

Philosopher Grice famously proposed the "cooperative principle"-that a conversation is, fundamentally, a cooperative activity. ${ }^{28}$ Both conversation partners act to comply with Grice's four maxims (quantity, quality, relation and manner) - to make their contributions as informative as is required, to be accurate and truthful, to be relevant, and to be brief, orderly and clear. ${ }^{29}$ His theory of implicature holds that one conversation partner will interpret what the other has said as a cooperative and coherent action that makes sense in context. ${ }^{30}$ In studying transcripts of interviews, these theories should be borne in mind in order to understand what typical conversation partners-especially clients-tend to do.

Sociologist Erving Goffman's theories of "facework" are also important to consider when studying interview conversations. When people interact,

22 Ainsworth-Vaughn, supra note 13, at $45^{8}$.

23 Id. at $455-56$.

24 Id. at 455.

25 Deborah Cameron, Working with Spoken Discourse 13, 31 (Sage 2001 ).

26 Id. at 48.

27 Id. at 48 . Ordinary language philosophers include J. L. Austin, John Searle and H. Paul Grice.

28 Id. at 75 (citing H.P. Grice, Logic and Conversation, in 3 Syntax and Semantics 45 (P. Cole \& J. Morgan, eds., Academic Press, 1975)).

29 Id.

30 See also Ronald Wardhaugh, An Introduction to Sociolinguistics 29, i-2 (2nd ed., I992); Grice, supra note 28 , at 45. 
they present their "faces" to each other. Each is interested in "saving face" and in protecting the other's face. We play out this little drama, cooperating to allow both of us to preserve our positive images. ${ }^{31}$ Certain factors increase how face-threatening an encounter will be-social distance, relative power, and degree of imposition. ${ }^{32}$ Thus, some attorney-client conversations will be face-threatening to a client, especially to the powerless, socially distant client asking for significant help.

Brown and Levinson's theory of politeness builds upon Goffman's theories about face. Certain ways of expressing ourselves-especially the tendency to be indirect-advance politeness but may harm clarity. ${ }^{33}$ Insup Taylor noted that "English speakers make over $90 \%$ of their requests in an indirect manner" ${ }^{34}$, thus, a lawyer's directness may be off-putting to the client and the client's indirect request may not be picked up by the attorney.

Finally, as we know from conversation analysis, conversation proceeds in certain orderly ways. Conversation partners take turns and rarely interrupt one another. ${ }^{35}$ Conversations begin and end in certain orderly ways. Conversations focus on "topics" that may be maintained or changed under certain situations. Certain conversational moves are expected-adjacency pairs of questions and answers, requests and responses, for example. ${ }^{36}$ There are certain kinds of talk-"spoken narratives" or "troubles talk" or "accountings" or "self-disclosures"-that may figure in legal interviews.

The typical spoken narrative ${ }^{37}$ has an identifiable structure:

\section{Abstract:}

[A] clause summarizing the point of the story/how it is supposed to be taken

31 Erving Goffman, The Presentation of Self in Everyday Life (1956); On Face Work: An ANalysis of Ritual Elements in Social Interaction (I955) reprinted in InTeraction Ritual 5 (1967); Frame Analysis (1974); Forms of Talk (1981); Felicity Conditions (1983).

32 Karen Tracy, The Many Faces of Facework, in Handbook of Language \& Soc. Psychol. 209, 2 I I (Howard Giles \& W. Peter Robinson, eds. 1990).

33 Penelope Brown \& Stephen Levinson, Politeness: Some Universals in Language Usage (1987). See also Deborah Tannen, Conversational Style: Analyzing Talk Among FRIENDS I I ( I 984 ).

34 Insup Taylor, Psycholinguistics: Learning and Using Language 36 (ig9o) (citing R.W. Gibbs, What Makes Some Indirect Speech Acts Conventional?, 25 J. Memory \& Language I 8 I-96 ( I 986)).

35 Harvey Sacks, Emanuel Schegloff \& Gail Jefferson, A Simplest Systematics for the Organization of Turn-Taking for Conversation, 50 LANGUAGE No. 4, 696 (1974). "Less than 5 percent of utterances overlap other utterances ...." WARDHAUGH, supra note 30, at 298.

36 Elaine Chaika, Language: The Social Mirror 12 I (1986); Taylor, supra note 34, at 36-37; WardhaUGH, supra note 30, at 302-03.

37 William Labov \& Joshua Waletzsky, Narrative Analysis: Oral Versions of Personal Experience, in Essays on the Verbal and Visual Arts 12-44 (J. Helm, ed., 1967). 


\section{Orientation:}

3. Complicating action:

4. Coda:

5. Evaluations:

\begin{abstract}
[A] series of clauses filling in the background information ....

... [D]escribes an event. The clause order is understood to represent the order of events in reality, so this section moves the story forward in time from the beginning to the end ....

[A] section that shifts to present time-reference to restate the meaning or moral of the story ....

[T]alk in which the action has been temporarily suspended and the narrator comments on the action from outside the story .... ${ }^{38}$
\end{abstract}

Certain parts of the narrative (the abstract, coda and evaluation sequences) "do not advance the action, but are designed to convey how the narrator from her/his present perspective views the events being related." 39

Another structure in conversation is self-disclosure, ${ }^{40}$ which can be direct or indirect and can be explicitly called for or simply permitted by the other conversation partner's questions or statements. The person disclosing information may work to bring about the topic, and the response he receives will encourage or discourage further revelations. Self-disclosure is often sensitive and creates a face-threatening situation. Accordingly, various management techniques are employed. These include "working a disclosure into a conversation in a smooth and natural way, [so] the face-threatening implications of disclosing should be lessened." 41 Persons disclose bad facts indirectly and by blaming others ("He gave me a D" rather than "I earned a D") to maintain face. Direct requests that call for negative self-disclosures most threaten face. The timing of self-disclosure can be important. "In general, a person who discloses later in a conversation is evaluated more favorable than one who makes the same disclosure early in a conversation." 42

A third kind of talk that may occur in client-attorney conversations is an accounting, "a linguistic device employed whenever an action is subjected to valuative inquiry." 43 Speakers use excuses to deny responsibility for

\footnotetext{
38 CAmeron, supra note 25 , at $152-53$.

39 Id. at I53-54.

40 Thomas Holtgraves, The Language of Self-Disclosure, in Handbook of Language \& Soc. Psychol. I9I (Howard Giles \& W. Peter Robinson, eds. 1990).

41 Id. at 198.

42 Id.

43 Michael J. Cody \& Margaret L. McLaughlin, Interpersonal Accounting, in HaNDBOoK of Language \& Soc. Psychol. 227 (Howard Giles \& W. Peter Robinson, eds. 1990).
} 
bad facts and use justification to make bad facts appear less negative. Excuses include appeals to accidents, biological drives, defeasibility, and scapegoating. Justifications include denying any injury, denying there was a victim, appealing to loyalty, and condemning the condemners. ${ }^{44}$

In order to properly teach, critique, and theorize about how attorneys should interview clients, we should understand that clients will be inclined to engage in this conversation as they engage in any other conversation and that certain aspects of a legal interview will create particular conversational challenges for clients.

Just as conversation analysis has been used to study and learn about ordinary conversation, it can be used to study and learn about legal interview conversations. There have been a handful of studies of lawyer-client conferences, using some variation of discourse, linguistic or conversation analysis. ${ }^{45}$ Many of these studies have focused on the unhelpful ways in which lawyers have asserted control over their clients.

Hosticka studied "paralinguistic aspects" of conversation (control of floor, control of topic, and question form) and concluded that the legal services lawyers "exercised considerable control" and "exclusive control" over how the client's problem was defined and what was to be done about it. $^{46}$ Danet and Bogoch also analyzed a legal aid interview considering question form, interruptions and topic control and concluded that the attorney controlled the client's problem to convenience the bureaucracy of the office and to discredit the client. ${ }^{47}$ Felstiner and Sarat conducted an ethnographic study of many attorney-client conferences in many divorce

44 Id.

45 See Austin Sarat \& William L. F. Felstiner, Lawyers and Legal Consciousness: Law Talk in the Divorce Lawyer's Office, 98 YaLE L. J. 1663 (1989); Austin Sarat \& William L. F. Felstiner, Law and Strategy in the Divorce Lawyer's Office, 20 LAw \& Soc'y Rev. 93 (1986); Bryna Bogoch \& Brenda Danet, Challenge and Control in Lawyer-Client Interaction: A Case Study in an Israeli Legal Aid Office, 4 Text 249 (1984); Peggy C. Davis, Contextual Legal Criticism: A Demonstration Exploring Hierarchy and "Feminine" Style, 66 N.Y.U. L. Rev. 1635 (1991); Gay Gellhorn, Lynne Robins \& Pat Roth, Law and Language: An Interdisciplinary Study of Client Intervieres, I CLINICAL L. Rev. 245 (1994); Gay Gellhorn, Law and Language: An Empirically-Based Model for the Opening Moments of Client Interviews, 4 Clinical L. Rev. 32 I ( I998); Carl Hosticka, We Don't Care About What Happened, We Only Care About What is Going to Happen: Lawyer-Client Negotiations of Reality, 26 Soc. Probs. 599 ( 1979); Gary Neustadter, When Lawyer and Client Meet: Observations of Interviewing and Counseling Behorvior in the Consumer Bankruptcy Law Office, 35 BufF. L. REv. 177 (1986); Don Peters \& Martha M. Peters, Maybe That's Why I Do That: Psychological Type Theory, The Myers-Briggs Type Indicator, and Learning Legal Interviewing, 35 N.Y.L. ScH. L. REv. 169 (1990); Linda F. Smith, Interviezing Clients: A Linguistic Comparison of the "Traditional" Interview and the "Client-Centered" Interview, I Cuinical L. Rev. 541, (1995) [hereinafter Smith, Interviewing Clients]; Smith, Client-Lareyer Talk, supra note I2. Discourse analysis has also been used, probably more extensively, to examine talk in the courtroom. See also Brenda Danet, Language and the Law: An Overview of 15 Years of Research, in HaNdBook OF LaNGauge AND Social Psychology 537 (Howard Giles \& William P. Robinson eds., I 990).

46 Hosticka, supra note 45.

47 Bogoch \& Danet, supra note 45. 
cases, describing a discourse in which the lawyers portrayed the judicial system as uncertain and personal, increasing the clients' dependence on them, and trying to get the clients to downplay their emotions. ${ }^{48}$ Neustadter observed six bankruptcy attorneys and observed most behaved as if selling a "product" (either a chapter 7 or 11 bankruptcy) but two were "clientcentered" in sharing the control of the "content, sequence and length" of the interview.

More recently, research has included law student interviews. Professor Davis identified two methods of law student interviewing in mock interviews: the inquiry method in which the facts are elicited by questions based on the student's sense of what is relevant and the conversation or collaboration method in which the problem context and client perspective are probed. ${ }^{49}$ Professors Don and Martha Peters studied clinic students interviewing indigent clients seeking divorces and observed few open questions and little active listening, despite their having been taught these interview approaches. ${ }^{50}$ Gay Gellhorn, Lynn Robins and Pat Roth teamed law and anthropology students to conduct and study interviews of clients seeking disability benefits. ${ }^{51}$ They concluded that clients often presented significant information in the opening exchanges of the interview (which students typically missed since they thought they were ice breaking) and clients continued to recycle this information until acknowledged, often leading to longer-than-necessary interviews. ${ }^{52}$

In my prior article about interviewing, I studied the "client-centered" interviews done by my best students with extemporaneous actors and analyzed interruptions, control of the floor, and question type. ${ }^{53}$ I concluded that the "client-centered" interview can be much less controlling that the "traditional" interviews criticized by Hosticka, Danet, Neustadter and others. The study presented here continues to use the analytical approach developed in that article but employs it on these two very different interviews by experienced attorneys interviewing outside their areas of expertise.

\section{ANAlysis of Interview Data}

After videotaping and transcribing the two interviewers, two researchers trained in linguistics coded each transcript noting interruptions, control

48 Sarat \& Felstiner, supra note 45.

49 Davis, supra note 45.

50 Peters \& Peters, supra note 45.

51 Gellhorn, Robins, \& Roth, supra note 45.

52 Id.

53 Smith, Interviewing Clients, supra note 45 , at 555-56. 
of the floor, type of utterance, and question type. ${ }^{54}$ The chart below summarizes this data.

\begin{tabular}{|c|c|c|c|c|}
\hline \multicolumn{5}{|c|}{ Conversation Analysis Data } \\
\hline & Attorney $\mathbf{A}$ & $\begin{array}{l}\text { A's Client } \\
\text { Vic }\end{array}$ & Attorney B & $\begin{array}{l}\text { B's Client } \\
\text { Vicki }\end{array}$ \\
\hline Time of Interview & \multicolumn{2}{|c|}{ 29:07 } & \multicolumn{2}{|c|}{$35: 36$} \\
\hline Floor Time Total & $12: 01$ & $17: 06$ & $19: 39$ & $15: 57$ \\
\hline Talking & $7: 45$ & $17: 06$ & $18: 56$ & $15: 57$ \\
\hline Pausing & $4: 16$ & & $: 43$ & \\
\hline Percentage & $41 \%$ & $59 \%$ & $55 \%$ & $45 \%$ \\
\hline Turns & 61 & 61 & 179 & 179 \\
\hline Interruptions Total & \multicolumn{2}{|c|}{15} & \multicolumn{2}{|c|}{96} \\
\hline Interruptions & 4 & 11 & 46 & 50 \\
\hline$\%$ Turns Interrupted & $7 \%$ & $18 \%$ & $26 \%$ & $30 \%$ \\
\hline Interrupt'n Frequency & \multicolumn{2}{|c|}{0.5 per minute } & \multicolumn{2}{|c|}{2.7 per minute } \\
\hline $\begin{array}{l}\text { Minutes Between } \\
\text { Interruption }\end{array}$ & $7: 15$ & & $00: 42$ & \\
\hline Competitive & $1 / 25 \%$ & $1 / 9 \%$ & $31 / 67 \%$ & $23 / 38 \%$ \\
\hline Cooperative & $3 / 75 \%$ & $10 / 91 \%$ & $15 / 33 \%$ & $31 / 62 \%$ \\
\hline
\end{tabular}

54 There was substantial agreement between the coders regarding time of talk and interruptions. Where there was disagreement I used the more negative data for Attorney $A$ and the more positive data for Attorney $B$. There was substantial agreement on coding utterance types and question form and where there was disagreement I determined the correct category consistently between Interview $A$ and Interview $B$. 


\begin{tabular}{|l|l|l|l|l|}
\hline Utterance Type & & & & \\
\hline Imperative & 1 & & 0 & \\
\hline Leading Q & 5 & & 37 & \\
\hline Yes/No Q & 34 & & 50 & \\
\hline Narrow Q & 8 & & 8 & \\
\hline Open Q & 8 & & 14 & \\
\hline Total Qs & 56 & & 109 & \\
\hline Time Questioning & $4: 45$ & & $6: 37$ & \\
\hline Time NOT Q'ing & $3: 00$ & & $12: 19$ & \\
\hline \% Time Q'ing & $60 \%$ & & $34 \%$ & \\
\hline
\end{tabular}

\section{A. Control of Floor}

The first issue I consider is who dominated or controlled the conversation. To do that I have measured the amount of time each person talked-"time of talk." ${ }^{55}$

My prior "client-centered" interviews involved fairly equal division of "floor time" between student attorneys and their clients, with clients speaking $41 \%, 51 \%$ and $53 \%$ of the time. ${ }^{56}$ (The one student who talked substantially more than the client did so in order to explain the interview, office procedures, next steps and a bit about the applicable law.) I would expect a good interview by a novice attorney to involve the client talking at least half of the time, since the lawyer would not be able to provide advice and counsel and would best use the time to discover what had happened and what the client wanted as a goal.

Here Attorney A controls the floor for considerably less time (41\%) than the client including substantial pauses to review the client's documents. This permitted the client Vic to speak $59 \%$ of the time. This division of "floor time" suggests substantial deference to the client. This is even more noteworthy because only 2 minutes and 20 seconds of the client's talk consisted of the initial narrative which is typically when the client asserts substantial control of the floor. ${ }^{57}$ Thus, Attorney A provided substantial

55 In conversation analysis of ordinary talk, control of the conversation is often determined by who selects the topics that are the subject of discussion and who changes the topic. As asserted in my prior study of interviewing, topic selection is not a good metric for control of a legal interview. One expects the client to provide information about the problem (thus selecting the topic), and one expects the attorney to pursue the problem in light of the law-questioning further about some aspects and inquiring about issues not expressly raised by the client. See Smith, Interviewing Clients, supra note 45 , at 56I-62.

56 Id at 562-64.

57 Professor Davis's students held the floor approximately $1 / 3$ of the time, but the client's 
additional times for the client to explain aspects of the problem and the goals. In contrast Attorney B spoke substantially more (55\%) than the client Vicki (45\%) suggesting a less successful interview.

Attorney A completed the interview, as instructed in "no more than $\mathbf{3 0}$ minutes" while Attorney B went 5 minutes and 36 seconds over the time limit.

\section{B. Interruptions}

Control of the floor cannot be adequately assessed without considering the related question of interruptions. Interruptions are simultaneous speech, and can indicate control or a struggle for control. ${ }^{58}$ In ordinary conversation only $5 \%$ of turns are interrupted. ${ }^{59}$ Attorney A succeeded in conducting his questioning and commenting in a way that closely approximated ordinary conversation. Each speaker took 61 turns and Attorney A interrupted Vic only four times or $6.5 \%$ of Vic's turns. In 29 minutes of conversation, Attorney A interrupted Vic only once every 7:15 minutes. This is greater deference to the client than the attorneys in Hosticka's study (10.4 interruptions per half hour or once every 3 minutes) or than any of the students in my prior study (they interrupted 6,11 and 16 times or once every $1: 20,2$, or 4 minutes). ${ }^{60}$

Linguistics professor Deborah Tannen makes the point that an interruption (or overlapping speech as she prefers to call it) may be a power play to wrest control of the conversation or may signal cooperative enthusiasm of two people talking together in agreement. ${ }^{61}$ Accordingly, each interruption was coded as "competitive" or "cooperative and supportive," with cooperative interruptions occurring when one speaker repeats what the other has said or begins to provide an answer before the question is completed, often occurring at the end or beginning of utterances. Competitive interruptions occur when one speaker attempts to change the subject or insists on a response different than the one the other speaker is providing, often occurring mid-utterance and indicating a struggle for control..$^{62}$ It is noteworthy that only 1 of Attorney A's 4 interruptions was considered "competitive."

control was directly related to the length of the client's opening narrative. Davis, supra note 45 , at 1663 .

58 See Smith, Interviewing Clients, supra note 45, at 557-6r. Interruptions do not include "back channel cues" ("uh-huh" ... "good" ... "I see") in which there is no struggle for or change in floor control even though there is simultaneous speech.

59 Id. at 558 (relying upon Bogoch \& Danet, supra note 45 , at 254-55).

$60 \mathrm{Id}$. at 558 ; Hosticka, supra note 45 , at 605.

6i Deborah Tannen, Gender \& Discourse 35-36 (1994); Deborah Tannen, You Just Don't Understand: Women and Men in Conversation, I88-2 15 ( I990).

62 Smith, Interviewing Clients, supra note 45 , at 557. 
It is also important to consider whether the client interrupted the attorney. Attorney A's client Vic interrupted him 11 times, with only 1 client interruption being of the competitive variety. Together there were a total of 15 interruptions or 1 interruption every 2 minutes, almost all cooperative.

This data on interruptions and control of floor paints a picture of an interview in which the client is ceded substantial control over the conversation, getting to talk the majority of the time and being interrupted no more often than one is in ordinary conversation. Attorney A's client Vic interrupted cooperatively 10 times, for example to provide the answer before the question was finished, and interrupted in a competitive way only one time.

A study of the data on interruptions in Attorney B's interview paints a starkly different picture. In that 35-minute interview there were 179 turns taken by each person and 96 total interruptions. Attorney B interrupted his client Vicki 46 times and Vicki interrupted Attorney B 50 times. Thus, on average, Attorney $B$ interrupted his client every 46 seconds and the client interrupted Attorney B every 43 seconds, so there was an interruption every 22 seconds. Another way to express this is that there were 2.7 interruptions every minute. Although the majority ( 31 or $62 \%$ ) of the client's interruptions were coded as "cooperative," a majority of Attorney B's interruptions (31 or $67 \%$ ) were considered "competitive." Competitive interruptions may indicate a struggle for control and difficulty directing the other party to provide the information required. So many turns and so many interruptions raises not only an issue of a struggle for control, but also a question as to how well either party was understanding the other in this fast-paced and fast-changing conversation.

While all prior studies of attorney interviews have found more interruptions than in ordinary conversation, Attorney A may disprove this charge. I previously hypothesized that we may simply need to accept the fact that legal interviews have many interruptions, given that it is usually time-bound and both conversation partners have significant goals they wish to accomplish. However, Attorney A's performance may suggest otherwise-it suggests that a confident and calm lawyer can competently conduct a legal interview in which he interrupts his client no more than ordinary conversation partners and yet learns the maximum amount of information in the time provided.

\section{Forms of Utterance}

Another item of study in interviews is the types of utterances by the attorney. Some have taught that in an "interview, the majority of communication from lawyer to client takes the form of questions." 63 Researchers doing

63 Binder \& Price, Legal Interviewing and Counseling, supra note 2, at 20. 
conversation analysis have argued that the attorney asserts control (and sometimes coercive control) by questioning and, particularly, by over-use of leading or yes/no questions. ${ }^{64}$ Accordingly, each interview was coded for type of utterance using the same formula used in my prior study ${ }^{65}$ which included identifying imperatives, ${ }^{66}$ leading questions, ${ }^{67}$ yes/no questions, ${ }^{68}$ narrow questions ${ }^{69}$ and "open Wh" questions. ${ }^{70}$

Prior studies have found lawyer questioning to be controlling or coercive. $^{71}$ Bogoch and Danet found the lawyer asked 79 questions and $75 \%$ were coercive leading or yes/no questions; Hosticka found $90 \%$ of the lawyer's utterances seeking to control with leading questions making up $21.8 \%$ of the questions; and Peters and Peters found $19 \%$ of the questions to be leading and only $6 \%$ open-ended. ${ }^{72}$ However, I argued ${ }^{73}$ that when leading questions serve to confirm facts that the client had stated during a narrative, such questions do not demonstrate coercion or control. Instead, it is more appropriate to look to the leading questions that seek new information in assessing whether the interviewer was coercive or controlling.

On any measurement involving question form, Attorney A out-performs other attorneys in avoiding unhealthy control. Attorney $A$ used 1 imperative and asked 5 leading questions out of 56 utterances; so only $11 \%$ of these 56 utterances were of this most controlling variety. There were 34 yes/ no questions (61\%) and 8 narrow questions (14\%) and 8 open questions (14\%).

In stark contrast Attorney B asks twice as many questions (109). Attorney B asked 37 leading questions (33\%) and 50 yes/no questions $(46 \%)$ combined to represent $79 \%$ of the questions of this most coercive

64 See Bogoch \& Danet, supra note 45, at 260; Hosticka, supra note 45, at 605-06; Peters, supra note 45 , at 187 .

65 Smith, Interviewing Clients, supra note 45 , at 567-69.

66 Imperatives were defined as orders, such as: "Give me the complaint."

67 A leading question was defined as a question which suggests a "yes" answer, including statements with "tag" endings, such as "You gave him the contract, didn't you?"

68 "Yes/No" questions were questions requiring either a "yes" or a "no" response, but not suggesting either, such as "Did you have a contract?"

69 "Narrow" questions and requests ask for a brief answer response. For example, "What day were you served?"

70 "Open 'Wh' questions" and requests invite a narrative response. For example: "What was the discussion regarding the weak sales?"

71 Smith, Interviewing Clients, supra note 45 , at 565 n. $99 \& 100$.

72 See Bogoch \& Danet, supra note 45, at 260; Hosticka supra note 45, at 605-06; Peters, supra note 45 , at 187 .

73 My prior students also asked many leading questions (29-59\%) and yes/no questions $(28-61 \%)$ but most of the leading questions (88-100\%) were used to confirm facts that the client had stated during a narrative. See Smith, Interviewing Clients, supra note 45 , at 565-72. 
variety much like the Bogoch and Danet lawyer. Attorney B asked 8 narrow questions and 14 open questions (13\%).

Again, however, it is important to study the content of the conversational exchange to determine if these question forms resulted in undesirable control or coercion by the attorney. Discourse analysts of doctor-patient interviews have raised two issues of control-control over the "emerging discourse" and control over "future action"-and have focused on the talk itself to determine whether it is conversation-like or more like a structured interrogation. ${ }^{74}$ I have argued that Gricean cooperative principles of conversation inspire the client to provide the relevant information that is called for on each topic, irrespective of question form. ${ }^{75}$ Accordingly, in studying question form and control over the emerging discourse, it is necessary to see if the attorney constrains or confines the client's answers by question form and interruption, or whether the client is permitted to provide sufficient detail to be relevant and responsive no matter the form of the question.

\section{Transcripts of Attorney-Client Interview Talk}

Although the data relied upon above is the sort of information that social scientists look to when comparing power in professional/patient-client conversations, it may be less convincing to the audience of law students and lawyers than are the transcripts themselves. Comparing the texts of the transcripts of the two interviews will produce a more grounded and richer understanding of these interviews.

There is a second reason why comparing the transcripts is informativeto correct for false impressions students may have gained from watching lawyering in movies or reading mock dialogue in texts. Many students watch their own recorded performances of client interviewing or counseling and, comparing themselves to actors in movies or on TV, the students feel inadequate. Of course, this is flawed comparison. Actors who have learned a script do not engage in many of the behaviors that we all do in conversation. One does not hear "back channel cues" (u-huh, mhm, go on) in the movies, although they are crucial in ordinary conversation. Typical conversation involves self-correction and self-interruption which is never written into a script for Hollywood. Thus, reading real transcripts of lawyers and extemporaneous actors will provide a more realistic touchstone for our students and us. Secondly, some texts include illustrative dialogue which, similarly, may suggest that lawyers should sound like that written dialogue when conversing with clients rather than sounding like themselves in conversation.

74 See Ainsworth-Vaughn, supra note 13, at 453-56.

75 Smith, Client-Lawyer Talk, supra note 12, at 507-08, 523-28. 
In comparing the content of the two conversations, I also show how the interview by Attorney A permitted the client to set forth the problem early and in his own words and gave the client substantial time and space to make "disclosures" - to share less-than-positive facts about the situation. In the other interview Attorney B pursued irrelevant issues and did not actually discover the problem until $1 / 3$ of the interview was over. Attorney A comes away with much more useful information than does Attorney B. To reach these conclusions I compare the topics covered in each interview, noting when Attorney A would be better positioned to counsel the client and develop a plan for dealing with the problem.

Finally I grapple with the mystery of the client responses to the interviews. Attorney B's female client Vicki rated that interview more favorably than did Attorney A's male client Vic. What could explain that? And how should we factor such client assessments into what we teach our students and what we do as interviewers?

\section{A. Openings}

The attorneys knew very little about the client or his case prior to the interview-only the client's name and that the problem dealt with a particular opposing party in an employment matter. Both lawyers began the interview ${ }^{76}$ by reflecting what they knew, and asking or permitting the client to present the situation in his or her own words. (This much is good in both cases. It respects the clients by informing them what the attorney does and does not know and it invites the clients to present the situation in their own way and words).

\section{Attorney A Interviews Client VIC \\ Attorney: My secretary told me that you called and had a question about an employment matter involving Leslie Swenson. We've run a conflicts check and there are no conflicts so we can represent you and you've signed an engagement letter so all the important housekeeping matters have been taken care of. Let's get started. ${ }^{77}$}

76 I have declined to analyze or discuss the opening greetings or "ice breaking" between attorney and client which Professor Gellhorn has argued often contains important disclosures by the client which the attorney misses. See Gellhorn, supra note 45 . I did not study that stage because the protocol for meeting and setting up the videotaping seemed awkward and most unlikely to compare with what might occur in an actual attorney-client interview. Accordingly, the "opening" starts with beginning to discuss the client's matter.

77 Interview by Attorney A with Vic I, in Salt Lake City, Ut. (May I 5, 1995) [hereinafter Interview by Attorney $A$ with $\mathrm{Vicl}$ (on file with author). 


\section{Attorney B Interviews Client VICKI}

Attorney: My secretary tells me that your problem has something to do with employment but I don't know what.

Client: [That's right]

Attorney: Tell me a little bit about what your problem is and what role you play in this employment picture. ${ }^{78}$

Attorney A characterizes the reason for the visit as "a question about an employment matter." 79 This effectively puts a neutral frame on the reason for the visit. In contrast, Attorney B refers to "your problem" having to do with "employment," characterizing the client as someone with a "problem" rather than someone with a "question." ${ }^{80}$ Framing the client's situation as a "question" rather than a "problem" no doubt permits the client to save face, which conversation analysts see as important. Although the client may well have a "problem" and may have done foolish things to create the problem, this introduction gives the client the benefit of the doubt about the situation and reason for engaging counsel. This also permits the client to "disclose" any "problem" in his own way and at his own pace, another lesson from conversation analysis.

While Attorney B might improve his opening by using more neutral terminology, this opening is generally in keeping with the universal suggestion that the interviewing lawyer invite the client to set forth the reason for the visit in her own words.

\section{B. The Client Describes the Situation}

Both clients respond by trying to tell a narrative about the source of the problem-Leslie Swenson-and both begin with hiring this sales person, explaining the compensation arrangements (commission with a draw), and identifying the problem of slow sales.

\section{Attorney A Interviews Client VIC}

Client: Okay, well, this is the silliest thing. Um, I hired

Leslie about a year ago(.) She, um, she was

on a commission versus-a draw versus commission

situation, standard salesman thing and she never made the amount of money that would offset her commission and uh, this is seven, eight months. Well, uh, I decided that the commissions were never going

78 Interview by Attorney B with Vicki 1, in Salt Lake City, Ut. (May 15, 1995) [hereinafter Interview by Attorney B with Vicki] (on file with author).

79 Interview by Attorney A with Vic, supra note 77 , at $\mathbf{I}$.

80 Interview by Attorney B with Vicki, supra note 78 , at $\mathbf{I}$. 
to-the draws were never going to add up to the commissions so what I did was I put a cap on the draws, and when I did that, uh, one of the salespersons, um, stayed on and took the challenge and went that route. Um, Leslie decided that she, um, didn't want to play by that because she wasn't, she wasn't making any commission anyway, so she just quit. Um, then somehow, uh, she claimed to the, uh, um, unemployment people that she had been laid off, or dismissed so she could get unemployment. I didn't think you could get unemployment if you quit. But somehow, she gave them a long, sad story and she is getting unemployment now which means my, my unemployment taxes go up ... Let me think. Uh ... so I was served with papers now, that she is suing me for compensation for the time that she did not sell anything after she left to pay her commissioned wage, her draw against future commissions which there couldn't be any ... So, since, since I paid her more than she was ever worth to the company, um, I don't think I should ever have to pay that, of course. And, uh, I want to know if there's any possibility that we can recover some of that money that we paid her that she really did not earn. $(00: 28-02: 48)^{81}$

\section{Attorney B Interviews VICKI}

Client: $\quad$ Okay. Well, our company hired a salesperson last February, at the end of February, who worked for us for about seven months and they were supposed to receive-he was supposed to receive commission, the $20 \%$ commission on his sales. The um, sales were very, very slow throughout the summer so we continued to give him a draw every month. And now $/ /$

Attorney: // A draw against his expected commission?

Client: $\quad$ Right. Against his expected sales which have been next to nothing. And when my husband finally said 'We've got to put a cap on this' after $\$ 11,000$. You know, he decided to cap it at thirteen and give them some incentive to get out and get busy selling//

Attorney: // So you've already paid him $\$ 11,000$ in advance

8I Interview by Attorney A with Vic, supra note 77, at I-2. 
and decided that you ought to make a cut-off point at $\$ 13,000 / /$

Client: Attorney:
//Right (01:33)

// in advance. I have to get a little information about the company, uh, to figure out whether this-what kind of numbers we're talking about. Um, what do you sell? $(00: 27-01: 48)^{82}$

1. Attorney A and Vic's Narrative.-Attorney A permits the client to complete this narrative (00:28-02:48), a task that takes only 2 minutes 20 seconds. $^{83}$ Although the client pauses for three seconds on three separate occasions, Attorney A does not re-claim the floor with a question or comment. As a result the client shares two problems (Leslie is claiming unemployment and suing the client's company for unpaid wages) and concludes with two goals-first not wanting to pay anything in the suit and second wanting to reclaim some of the money already paid. ${ }^{84}$

Attorney A permits the client to tell a narrative which contains certain points that some lawyers would deem "irrelevant." What the client does is tell a story with various elements of the prototypical conversational "spoken narrative" ${ }^{85}$, including: the opening "abstract" ("this is the silliest thing"); the "orientation" background information; the "complicating action" describing the event; a "coda" shifting to present time to restate the meaning ("she is getting unemployment now which means my unemployment taxes go up ... she is suing me"); and an "evaluation" commenting from outside the story ("So, since I paid her more than she was ever worth ... I don't think I should ever have to pay that ... I want to know if there's any possibility that we can recover some of the money. ... "). ${ }^{86}$ Yet Attorney A's silence has permitted the client not only to share the essence of his problems in narrative story-telling fashion, but also to share his attitude and his goals, all in under $21 / 2$ minures.

The effectiveness of this short, short narrative should convince controloriented lawyers that letting the client set forth the issue in his own words at the outset can sometimes be accomplished without wasting time. Of course, the attorney is far from understanding all the details of the problem and may even have a difficult time remembering everything that has been said in that short narrative. But fortunately, the attorney now has a solid

82 Interview by Attorney $B$ with Vicki, supra note 78 , at $1-2$.

83 Interview by Attorney A with Vic, supra note 77, at 1-2.

84 Id.

85 See infra section II.B, regarding "spoken narrative" in conversation; Smith, ClientLawyer Talk, supra note I2, at 51 I-1 2.

86 Id. See also Cameron, supra note 25, at 13. 
introductory understanding of both the essential problems and the client's goals.

It would appear that this introductory narrative comports with the suggested structure recommended by Cochran's and Krieger's texts. ${ }^{87}$ It is unclear whether it could also qualify as the "Preliminary Problem Identification" recommended by the Binder text as it contains the essential elements of problem description, desired outcome, means of achieving desired outcome, and legal and non-legal concerns. ${ }^{88}$ However, Attorney A does not follow the client's introductory "spoken narrative" with a "time line," but with questions following the chronology of the situation, perhaps combining the value of the a chronology and the value of the attorney's intentional questioning regarding relevant topics.

2. The Power of Narrative.-Understanding the "spoken narrative" structure used in ordinary conversation may be useful in helping interviewers listen through "irrelevant" comments that share the client's attitude without feeling the need to redirect the client to share only "relevant" facts. Accepting the power of narrative and the fact that many people choose to present their problems not as abstract statements of "a case" but as narrative stories is also important for professionals who conduct interviews.

It may be useful to understand that in this experiment, the actor-clients were in no way instructed to give a narrative. Nor were they presented with their "case" in this narrative framework. Instead, the actors received a packet with BACKGROUND (p. 1) a paragraph regarding the client company, then (p. 2):

\section{THE PROBLEM}

Your company (ACT) has just been sued by a lousy sales agent (Leslie Swenson) who just left in mid-October! Although the sales agent worked on commissions, the law suit asks for back wages. It also asks for some penalty and for attorney fees! (You've brought the complaint-attached.)

\section{YOUR GOALS}

Well, of course you want representation. And you want to make an informed, sensible business decision about this case. But you really don't want to pay this former employee-Leslie Swenson-a red cent. And you don't think you should have to. Finally, since you paid this no-good salesperson over $\$ 11,000$ in draws against future commissions, and the commissions earned were no where near that amount; you'd actually like to sue and get those loans-as you consider them-back.

Here's why you're entitled to what you want:

87 See Cochran et Al., supra, note 3; KrIEger et Al., supra note 3. 88 Binder, et Al., LaWyers as Counselors, supra note 3, at 86-89. 
"WHAT HAPPENED" begins on p. 3 with an account of the poor sales and the change to put a cap on the draws and then comes a HISTORY (p. 3-4) that describes hiring Leslie and Glen and the summer sale. ${ }^{89}$

Thus, this presentation would have lent itself to the actor-client beginning the conference by naming "the Problem" as a law suit and announcing his or her "Goals." The actor-clients' choice to give a narrative of what happened (and in Vicki's case to include facts from the p. 4 History regarding the summer sale), was not induced by the presentation of the material but chosen by them in their roles as extemporaneous actors. In fact, in this experiment two of the actual people from the case were also interviewed by students and lawyers. These interviews seemed to contain the longest and most detailed narratives. The one interview with an attorney and actual party that was transcribed produced a 3 minute $3 \mathbf{I}$ second narrative in response to the question "What sort of problem do you have?"

3. Attorney B Interviewes Vicki.-Attorney B's opening minutes provide a stark contrast. Attorney B interrupts twice seeking clarification of what the client had said and then interrupts a third time to redirect the conversation to background information about the client's company (00:27-01:33), stopping the client's narrative after only 1 minute and 6 seconds of interrupted talk. ${ }^{90}$ While one might forgive the two clarification interruptions, as they guaranteed the lawyer would understand the client's tale, there is no justification for the third topic-changing interruption. Indeed, the lawyer's justification for seizing control (needing to find out more about the company to see "what kind of numbers we're talking about") raises two concerns. ${ }^{91}$ Then, the next question narrows one of them to ask what the company sells (not "tell me about your company").92 Even worse in light of conversational conventions, Attorney B has seized control to direct the conversation before the client has been able to comply with Attorney B's request ("tell me a little about what your problem is and what role you play in this employment picture") by naming the problem or her role. ${ }^{93}$

One is tempted to think that Attorney B is frustrated with narrative; that he simply wanted the client to name a problem-a law suit for unpaid wages. However, that may not have been Attorney B's situation. He did not interrupt to ask what sort of problem it was, but rather he did so to gather different background information about the company and then to

89 Instructions for Vic and Vicki for interview by Attorneys A and B I-4, Salt Lake City, Ut. (May 15, 1995) (on file with author).

90 Interview by Attorney B with Vicki, supra note 78 , at I-2.

91 Id. at 2.

92 Id.

93 ld. at $\mathbf{I}-2$. 
direct the narrative. Perhaps Attorney B just needs to feel or be seen as "in control."

Attorney B spends nine minutes directing the conversation with questions and with statements reflecting what the client has just said before the client is finally able to complete the story and reveal the problem she wants the lawyer to address. It is instructive to see the transcript of this next five minutes of questioning and guessing:

ATTORNEY B Interviews Client VICKI —- had just asked "What do you sell?"]

Client: $\quad$ (01:41) We sell computer software.

Attorney: Okay. And, um, how many salespeople do you have?

Client: We have two. My husband also does his sales.=

Attorney: =Okay. So you-the person you hired in February was one of two salespeople.

Client: Right.

Attorney: And, um, the other person is also on commission.

Client: Right. =

Attorney: =Same deal?=

Client: $\quad=$ Uh, huh.

Attorney: Uh, trouble with that person selling, the other person?

Client: Um, he-it was a very slow year. He finally identified a big client in Chicago and so that-he is now working for another company but he stayed on for an extra couple of months after Leslie quit.

Attorney: Now, Leslie is the person who/l

Client:

Attorney:

Client:

Attorney:

Client:

Attorney:

Client:

Attorney:

Client:

Attorney: Client:

Attorney: Client:
Right.//

//who we're talking about? Okay. So, uh// //Glen is the other one.=

=Okay. Glen continued on for a while Uh, huh.

Uh, and identified $/ /$

//made enough, made enough sales on his own. Was, was there a draw for Glen?

Well, right. [Yes] Both of their contracts are the same [Okay] and so we had paid him also in advance [Uh, huh] but, he has found//

Right. $=$

$/ / \mathrm{He}$, he scored big.

=And was able to generate it on sales to make up// //Right// 
Attorney:

Client: //for-okay. And how about Leslie? Any big sales?

During this minute of conversation Attorney B gets background information on the company (it sells software; there are two sales people with the same commission/draw arrangement) and then tries to explore a theory (Did both sales people have trouble?) about the identified problem (slow sales).

This early attempt to test a theory about the essence of the problem can threaten the client's face by not permitting the client to disclose bad facts in her own way at her own pace. It may ask a client to reveal weaknesses about a case before she has presented her best case ${ }^{95}$ and can result in clients being less than clear and candid.

This exchange also illustrates the danger of yes/no questions that occur prior to the narrative having been completed. Attorney B's question "[was there] trouble with that person selling, the other person" could have been answered "Yes" or "No" or, more accurately here "Yes, but not as much." 96 The client does not answer the question directly with a Yes or a No or even a qualified "Yes, but." responsive to the topic of how the other sales person did. She characterizes the year as "slow," claims the other salesperson identified a "big client" and then reveals that while this other salesperson stayed on for a while, he has also now left the company. ${ }^{98}$ This rather thorough response on the topic is illustrative of the Gricean cooperative principles-she is truthful, she is responsive to the topic named by the questioner, and she tries to say as much but not more than is needed.

Unfortunately by providing both a quick and thorough response, the client created a difficulty for Attorney B understanding and remembering all she has said. A reader of this transcript might continue to wonder if the "problem" was the company/product or the one poor salesperson, especially given this ambiguous report about the second sales person. But Attorney B seems to reach a more optimistic conclusion, as Attorney B summarizes that the other salesperson "made enough sales on his own" and "scored big," reflecting facts that Attorney B thinks he has heard. ${ }^{99}$ This illustrates the second problem with premature questioning driven by the attorney's

94 Interview by Attorney B with Vicki, supra note 78, at 2-3.

95 See Smith, Client-Lawyer Talk, supra note 12, at 508-10; Erving Goffman, The Presentation of Self in Everyday Life (1956) (regarding the desire to "save face" to present one's self in the best possible light).

96 Interview by Attorney B with Vicki, supra note 78 , at 2.

97 Id.

$98 \mathrm{Jd}$.

$99 I d$ at 3. 
theories-the attorney might not get the correct picture. This problem appears to have taken place.

Ultimately Attorney B reorients the client to where she was when he first interrupted and then finally asks an open question that should permit the client to complete her narrative:

\begin{tabular}{|c|c|}
\hline \multicolumn{2}{|c|}{ Attorney B Interviews Client VICKI } \\
\hline Attorney: & $(02: 57)$ \\
\hline & $\begin{array}{l}\text { Okay. All right. So we're at the point where a couple } \\
\text { of months ago or so Leslie is, uh, five months } \\
\text { into this deal= }\end{array}$ \\
\hline Client: & $=($ back channel cue $) / /$ \\
\hline Attorney: & $\begin{array}{l}\text { //There's-that's } \$ 2,000 \text { a month approximately } \\
\text { that you were advancing// }\end{array}$ \\
\hline Client & $\begin{array}{l}\text { //Right. And there was more at the first [Uh, huh] } \\
\text { and then I think it starts at like twenty-eight and } \\
\text { then the next month it was twenty-one and the next } \\
\text { month we were giving them } \$ 1,500 \text { a month [Okay] } \\
\text { against his future commissions.= }\end{array}$ \\
\hline Attorney: & $=$ Of which there haven't been very many. \\
\hline Client: & Right. \\
\hline Attorney: & Have there been some? \\
\hline Client: & Uh, a few here and there. But, still he, we// \\
\hline Attorney: & //So ( )// \\
\hline Client: & $\begin{array}{l}\text { //if he could sell, he still owes us basically } \\
\$ 11,000 \text {. He wants now ((short laugh) }\end{array}$ \\
\hline Attorney: & $\begin{array}{l}\text { Okay, so, uh, the falling out, a falling out has } \\
\text { occurred. Partly, I gather because you and your } \\
\text { husband own this business together. }\end{array}$ \\
\hline Client: & Right. 100 \\
\hline
\end{tabular}

In this segment Attorney B reflects the previously stated fact that there haven't been many commissions, asks more on that topic ("Have there been some?), and then prevents the client from jumping to the end of the story ("He wants now") by re-orienting her to where they were in the narrative ("Okay, so, .... a falling out has occurred"). One might guess that the client had become frustrated with the interruptions and the changing of topics, and sought to name the "problem"-the employee is suing us for a few thousand dollars. Interestingly, Attorney B appears not to want to know that bottom line, but rather wants the client to go back to where they were in the story and complete it. The interview continues:

Ioo Id. at 3-4. 


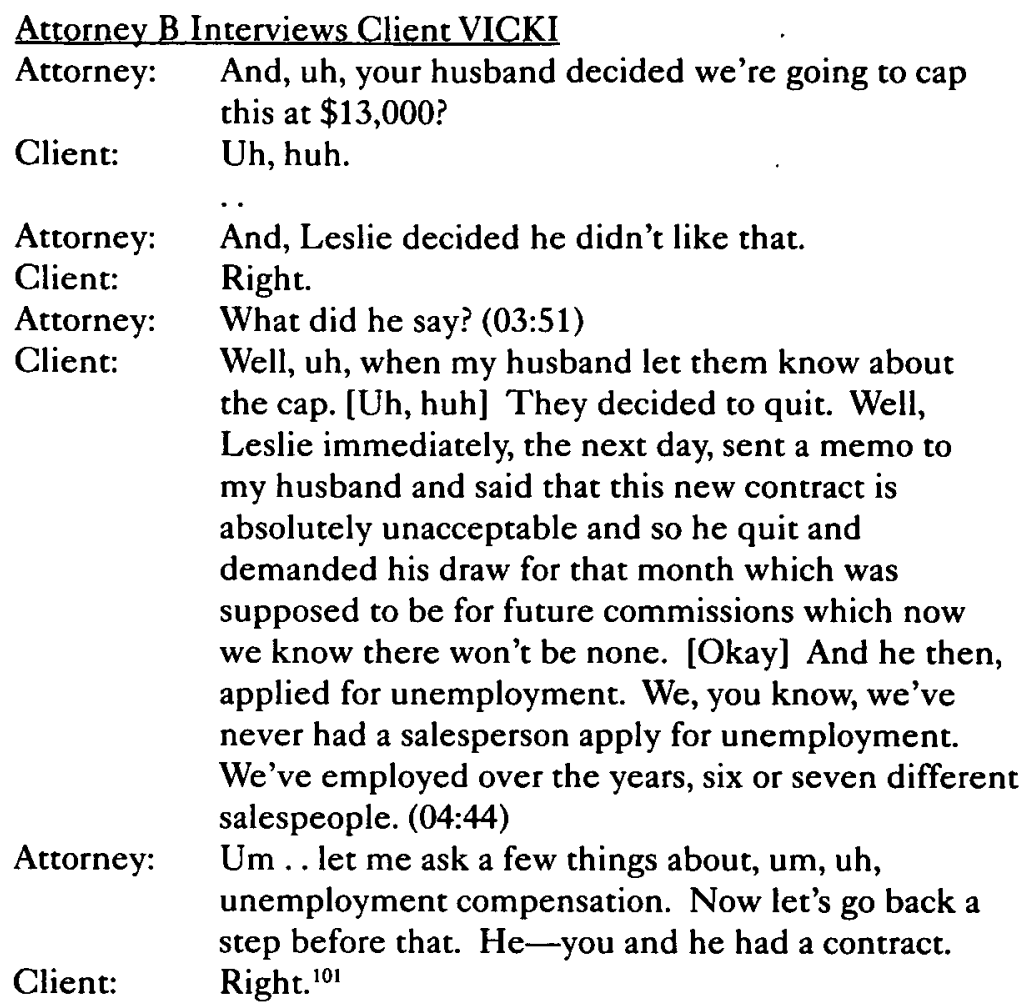

At this juncture the client has still not completed her narrative or been able to name the primary problem (a lawsuit) she wants the lawyer to address. The client is completing the "unemployment" narrative with a coda (explaining no one has ever applied for unemployment before) when Attorney B stops the narrative again. Perhaps because Attorney B is frustrated by the coda and the evaluation in this spoken narrative or, alternatively, because $B$ has heard a legal problem (unemployment) named, Attorney $B$ jumps in to question about the basis for unemployment liability. He then corrects himself and goes back to the other legal animal namedthe contract between the client company and its employee:

\section{Attorney B Interviews Client VICKI}

Attorney: Um, let's discuss a little bit about the nature of this contract [Okay] between you, you as the employer, so to speak, and him as the contractor or employee because unemployment compensation wants to focus on the relationship, I suspect, between you and 


$\begin{array}{ll} & \text { your-you and Leslie, you and your husband and } \\ \text { Leslie// } & / / \text { Yes.// } \\ \text { Client: } & / / \text { in terms of whether there's an } \\ \text { employment contract or some other kind of } \\ \text { contract and employer and employer } \\ \text { relations can be either as contract or } \\ \text { contractee [Uh, huh] or employer, employee. } \\ \text { [Uh huh] Let me give you an example. If } \\ \text { you need someone to paint your house. } \\ \text { He's not your employee,[Right] he's a } \\ \text { contractor.= }\end{array}$

Client: $\quad=$ No. Leslie was an employee. $=$

Attorney: =was an employee. Okay, so, um, then the question is did he have good cause to quit as the unemployment compensation would have it, uh, go ahead//

Client: $\quad$ //Well, they're paying him unemployment which means we'll pay more [Right] unemployment taxes even though, even though it's crazy. He actually, he lied to the agency. He said that he had been laid off which is absolutely untrue .. and then he wrote another letter to them and said that he had good cause to quit because it's going to be on a straight commission.

Attorney: Okay. Claims-he claims good cause, uh, for quitting after he had earlier said that he'd been laid off.

Client: $\quad$ Right.

Attorney: And unemployment hasn't said anything about that?//

Client: $\quad$ /Well, we called him on it. [Oh] He said that he had quit, uh, he said that he had been laid off and we said, "No, he quit once we decided to cap this free flowing fund of, you know, of our draw." $/ /(06: 38)^{102}$

Attorney B's attempt to direct the conversation by questioning about legal theories related to unemployment eligibility (whether Leslie was an employee or a contractor) leads nowhere as the client is certain that Leslie was an employee. Attorney B next turns to exploring whether Leslie had good cause to quit (a basis for unemployment) and the client interrupts to tell Attorney $B$ that this matter has already been determined by the unemployment compensation people.

102 Id. at $5^{-6}$. 
At that point Attorney B changes the subject away from unemployment and asks for documents.

\section{Attorney B Interviews Client VICKI}

Attorney: (06:38)//Now Leslie wrote you a letter in response of the notice, do you have a copy of the notice and a copy of the letter?

Client: I don't have a copy of the notice that my husband wrote. [Right] I'm sure we have it somewhere [Okay] but I brought, um, a notice that [Good] in fact it was attached to the, um, to something that we received $={ }^{103}$

The client tries to reply responsively while also trying to explain her primary concern, and she provides copies of what she has brought with her. She answers the question about the letter her husband wrote (I don't have a copy... [here with me]) and volunteers she should have it "somewhere". She then goes on to indicate that she has one of the requested documents (the letter from Leslie) and mentions that it is "attached to the, um, to something that we received" since the letter is an Exhibit attached to the Complaint which is the primary reason for seeing a lawyer. ${ }^{104}$ The client takes this opportunity to give Attorney $B$ the Complaint with the requested letter attached. Thus, the client is able to indirectly state the reason for her wanting legal help by giving Attorney B the Complaint because the document he asked about was attached to the Complaint.

This is an excellent example of the Gricean cooperative principles in action. The client cooperatively answers the question Attorney $B$ asks about documents and gives him one of the documents. But she also endeavors to make her utterance as informative and relevant as possible, by indirectly alluding to the lawsuit and providing a copy of the Complaint (calling it "something that we received") and apparently producing it only because the letter is attached to it. This female client has chosen this polite and indirect way of sharing relevant information ${ }^{105}$ rather than insisting (as another client might have), "Look here, I need to tell you our main problem-we are being sued by this jerk!"

103 Id. at 6-7.

$104 \mathrm{Id}$.

105 Linguistics professor Deborah Tannen has written extensively about the tendency to be direct or indirect in conversation, showing how directness varies with culture and gender (women tend to be more indirect in communication). See Deborah Tannen, That's Not What I Meant: How Conversational Style Makes or Breaks Relationships (i986); Deborah Tannen, You Just Don't Understand: Women and Men in Conversation (1990); Deborah TANNEN, Gender \& Discourse (1994). 
This ultimate but circuitous revelation of the primary problem should both warn and calm new interviewers. It should warn controlling attorneys that they may be best able to learn about the client's situation by listening to the client present her case rather than by controlling the early stages, guessing what the client's legal problem might be and posing questions thought to be related to that problem. Many clients are perfectly able to present their situations in a brief and orderly way, and this will permit the lawyer to better understand that situation. The attorney ought at least to try that approach in order to best and most clearly understand the information the client wants to convey. On the other hand, if a novice interviewer tries to control and jumps in prematurely with questions, this dialogue suggests that the client will soldier on to find a way to share her problem. She will reveal important information when she can and she will do so by responding to the topics the lawyer selects and including important information that is somewhat related to each topic. This pattern of providing relevant information that is somewhat related to the topic will surface again in these transcripts.

Now that the real legal concern has surfaced, Attorney B doesn't miss a beat but immediately begins to question about the Complaint while the client continues to answer the question about Leslie's letter.

\begin{tabular}{|c|c|}
\hline \multicolumn{2}{|c|}{ Attorney B Interviews Client VICKI } \\
\hline Attorney: & $\begin{array}{l}=\text { I've got to ask where we, uh, proceed fully whether } \\
\text { he has// }\end{array}$ \\
\hline Client: & $\begin{array}{l}\text { //Let me give you a copy. } \\
\text { [Okay] I've got a copy ... and its item ... } \\
\text { let's see ... it is at the back right after } / /\end{array}$ \\
\hline Attorney: & //Now, you were served this on what day? \\
\hline Client: & $\mathrm{Um} / /$ \\
\hline Attorney: & $/ /$ On the fourth. $=$ \\
\hline Client: & $=$ Right. The fourth of this month $/ /$ \\
\hline Attorney: & $\begin{array}{l}\text { //K, so we have to have an answer } \\
\text { filed within twenty days after that [Right] } \\
\text { which means about Christmas Eve we have } \\
\text { to have it filed. }\end{array}$ \\
\hline Client: & I know. Merry// \\
\hline Attorney: & $/ /$ Is that $\mathrm{a} / /$ \\
\hline Client: & $\begin{array}{l}\text { //Christmas to us. [Right] .. Uh, I } \\
\text { think it's exhibit B where he quits. He says, } \\
\text { um,.. "I understand both you and Vicki to } \\
\text { announce the termination of employment } \\
\text { agreement// }\end{array}$ \\
\hline Attorney: & //I'm sorry, I'm// \\
\hline Client: & \\
\hline
\end{tabular}


Attorney: down to where I was at exhibit $\mathrm{E}$.

//I'm, I'm, a few pages ...

Client: It's the next one. There//

Attorney:

$/ / \mathrm{B} / /$

Client:

Attorney:

//it is right there..... . Do you see that first paragraph, "Glen" $\longrightarrow$ or Third, I guess, paragraph//

//Right. "Glen and I both

understood you and Vicki to announce the, uh, termination of employment effective on November 15." (08:15)

Client: "I also understood the situation in light of the draw on commission report." Okay now, when we-when he demanded his extra, uh, compensation the [Uh, huh] the $\$ 750$ for those two weeks [Uh, huh] we called-he, you know, through all these laws, like I said, we were in violation of and, you know, we don't want to make this an ugly thing. We want it to be fair, we-I'm a good law abiding citizen so we called the Utah Commission, the Industrial Commission [Uh, huh] and they said to us that since a draw is on future commissions and there will be none, we only owed him minimum wage and so we paid him. (09:03) 106

After the client has identified her problem by handing the Complaint to Attorney B and has fully answered his questions about the letter Leslie had written, Attorney B is silent for a few seconds. The client Vicki takes this opportunity to complete the story up until being sued. It has taken nine minutes for the client to complete this narrative, given Attorney B's desire to control the conversation and pursue legal theories that might (or might not) be relevant.

4. Comparison of the Interviews in Learning the Clients' Problem.-It is universally agreed that the attorney's goals in the first interview are both factual and relational. The attorney wants to find out what happened and what the client wants done (problem/goal), and the attorney also wants to establish good rapport with the client. ${ }^{107}$ One can imagine that the

106 Interview by Attorney B with Vicki, supra note 78 , at $7-8$.

I07 Cochran et AL., supra note 3, at 55 (giving "the goals of effective legal interviewing" as "establish rapport with the client and gather information necessary . . . to represent the client"); KRIEGER ET AL., supra, note 3, at 78-81 (highlighting the purposes in interviewing 
client has similar goals-to tell the attorney what happened; what she is concerned about and what she would like to have as a result; hopefully, to get answers about her situation; and to establish a relationship in which she entrusts her situation to the lawyer.

When assessing and comparing these two interviews, it is useful to consider both informational and relational goals.

Attorney A's silence permitted his client Vic to set forth not only his problems but also his goals in under three minutes. However, a 2 minute 20 -second narrative may be much too fast for the attorney listening to take in and to recall all the important information conveyed. Therefore, the factual usefulness of this narrative must wait to be confirmed by what occurs in the questioning that follows.

Attorney B's biggest weakness in this interview was in not permitting the client to give a narrative to explain her situation and then controlling aspects of the telling of "what happened." This approach wasted time. It took Attorney B nine minutes (almost $1 / 3$ of the interview time) ${ }^{108}$ to discover what had occurred and what problem the client wanted addressed. Instead of permitting the client to present her problem as she chose, Attorney B pursued a number of dead-ends or red herrings that were not the client's problem-i.e., guessing that there may be an argument that Leslie was a contractor rather than an employee as well as guessing that the unemployment claim was the concern and might be defeated on the contractor/employee basis or on the basis that there was no "good cause" to quit. This demonstration should serve as a cautionary tale to attorneys who believe that they need to control the interviewing by questioning to enhance efficiency.

A second problem with the numerous interruptions and continual struggle for control of the floor between Attorney B and client Vicki is that this approach may have resulted in Attorney $B$ failing to hear and remember some of the important information that was conveyed. Attorney B seemed to believe "Glen" had "hit it big" when his situation was only somewhat better than Leslie's had been and he, too, has left the company. Finally, this interruption-filled approach, of the attorney guessing the problem and questioning based on those guesses, likely will not provide the best base for Attorney B to pursue the widest range of follow-up inquiries.

Turning to consider the rapport developed between these two attorneys and their clients, one should consider what was done and said, and theories about conversation as well as what the actor-clients reported. It would

clients as to form an attorney-client relationship, to learn the client's goals, to learn as much as the client knows about the facts, and to reduce the client's anxiety without being unrealistic).

108 The attorneys had been instructed to complete the interview in "no more than 30 minutes." Attorney A ended the interview in 29 minutes 07 seconds while Attorney B went over the time limit and spent 35 minutes 36 seconds in his interview. 
seem that Attorney A's permitting his client to deliver his spoken narrative uninterrupted would be positive for attorney-client rapport. The studies that criticize lawyers as sometimes being too controlling would support such an approach to empowering the client. Attorney B's questioning driven by theories might have threatened the client's face. For example, by asking if the other salesperson also had trouble selling the company's product, Attorney B was exploring whether there was something wrong with the company's product rather than with Leslie's selling skills. The client replied in a face-saving indirect way, evidence that the client may have felt threatened by the question.

Interestingly, here is what the two actor-clients reported about their interviews ${ }^{109}$

\begin{tabular}{|l|l|l|}
\hline RATINGS & $\mathbf{1 - 1 0}$ & Comments \\
\hline $\begin{array}{l}\text { Attorney A by Male Client } \\
\text { Rate how comfortable the } \\
\text { during the interview. }\end{array}$ & 8 & $\begin{array}{l}\text { VIC: Attorney A looked me in } \\
\text { the eye-a lot-it was good. Soft- } \\
\text { spoken, even "mousey", sounded } \\
\text { like he knew what he needed to } \\
\text { do. I could tell why he asked each } \\
\text { question and that was reassuring. }\end{array}$ \\
\hline $\begin{array}{l}\text { Attorney A by Male Client } \\
\text { inte how confident you felt } \\
\text { you. }\end{array}$ & 7 & $\begin{array}{l}\text { VIC: Could be tougher to give } \\
\text { an impression of strength. But } \\
\text { I never thought he would do } \\
\text { an incompetent job. The wage/ } \\
\text { cost/benefit analysis was a great } \\
\text { suggestion! }\end{array}$ \\
\hline $\begin{array}{l}\text { Attorney B by Female Client } \\
\text { Rate how comfortable the } \\
\text { attorney helped you feel } \\
\text { during the interview. }\end{array}$ & 9 & $\begin{array}{l}\text { VICKI: Very comfortable. } \\
\text { Although I didn't have all the } \\
\text { documents/facts he requested, he } \\
\text { gave me the opportunity to bring } \\
\text { them later. }\end{array}$ \\
\hline $\begin{array}{l}\text { Attorney B by Female Client } \\
\text { Rate how confident you felt } \\
\text { in the attorney representing } \\
\text { you. }\end{array}$ & 9 & $\begin{array}{l}\text { VICKI: Very confident-He knew } \\
\text { and referred to specific contract/ } \\
\text { wage laws and he knew what he } \\
\text { was talking about. }\end{array}$ \\
\hline
\end{tabular}

109 Ratings given by Vic and Vicki of interviews by Attorneys A and B, Salt Lake City, Ut. (May 15, 1995) [hereinafter Ratings given by Vic and Vicki] (on file with author). 
What should we make of the fact that the Female Client liked Attorney B so well? And better than the Male Client liked Attorney A?

First, it is useful to recall Avrom Sherr's study of initial interviews in which the clients rated their attorneys much higher than the faculty rated them, and even rated them higher than the attorneys rated themselves! We should consider that perhaps impressions following an initial interview are simply not that important to judging overall effectiveness of the attorney interviewer. Clients may be unduly impressed by an attorney's questions that seem grounded in legal theories, even when those theories are irrelevant or incompetent. This is at least one reason the client gave for having confidence in Attorney $B$ and, at this point, the client will not know whether any of those questions or theories are germane. It may prove more valid and useful to ask clients their assessments of their attorneys after the attorneys have counseled them and have begun to take action on their behalf.

Clients are different as conversationalists and as they orient themselves to professional helpers. It may be that some clients want a strong attorney to take charge, and will feel comfortable and confident based on this style. Here, it seems, the Male client Vic was reacting negatively to Attorney A's quiet style ("mousey") and encouraging him to "give a tougher impression." In contrast, the Female client Vicki appears to respect Attorney B's control, so much so that she faults herself for failing to bring all the documents and credits Attorney B for not being angry with her when she didn't have or know something.

These individual responses raise questions about how much we should (or can) do to alter the way we appear to clients during an initial interview. Surely we should be polite, concerned about the client, and empathic. Surely we should endeavor to find out about their situation and their goals. But I doubt that we should try to alter our conversation style for the benefit of first impressions during an interview. To some extent the way we are as conversationalists will not be alterable in major ways. Understanding our styles (and the places where our natural inclinations can lead us astray) may be as valuable as learning particular techniques.

\section{Follow-Up Questioning}

All authorities agree that the attorney should follow-up the client's narrative with questioning. ${ }^{110}$ Some authorities emphasize the usefulness of framing

I 10 The questioning that the attorney does after the client's narrative has been referred to as the "probing stage." KRIEger ET AL., supra note 3, at 75. It has also been referred to as "developing the client's story." Cochran, et AL., supra note 3, at 95. The Binder text recommends that "preliminary problem identification" be followed by a "time line" and then "theory development questions." Binder ET Al., LaWYERS as Counselors, supra note 3, at 149-92. 
the different stages of the interview and explaining how the lawyer wishes to conduct the interview. ${ }^{111}$

Attorney A conducts the remainder of the interview-26 minutes-in a relaxed and orderly way, with framing statements at appropriate spots. In contrast, Attorney B continues the pattern of questioning that he initiated less than two minutes into the interview, with little change in the dynamics of questioning, reflecting and interrupting. One issue to consider regarding the clearly delineated second stage of Attorney A's interview is whether this structure (short narrative followed by attorney-directed questioning) is effective in allowing the Attorney to learn the maximum amount about the client's situation and in allowing the client Vic sufficient opportunity to express himself.

1. Attorney A.-Attorney A first frames this part of the interview in a useful, non-face-threatening way-asking for the client's help in getting a better view of the "situation" and promising a later meeting to "come up with a game plan about how $w e$ want to proceed." 112 Attorney A structures the follow-up questioning to first cover what had happened in chronological order, and to then turn to the present and future -asking about the effects of the law suit and possible solutions. In this way, perhaps, Attorney A combines the "time line" and "theory development questions" into one stage.

Attorney A asks open, closed and yes/no questions in chronological order, asking for relevant information about each stage of the employment relationship. The form of the question appears not to be important, as the client provides the relevant information he has on each topic raised by Attorney A. Attorney A does not debate any legal theories or ask any questions that would threaten the face of the client. A review of the beginning of this stage of the interview is instructive.

Attorney A Interviews Client VIC

Attorney: (02:48) What I'd like to do would be to get your help getting sort-of a better view of the situation [Okay] and then, um, we can get together later and come up with a game plan about how we want to proceed.

[Okay]

Um, will you tell me a little more about your company and what it does?

I I See Binder, et al., Lawyers as Counselors, supra note 3, at $103-08$ (regarding the benefits of a "preparatory explanation" at the conclusion of the "preliminary problem identification"); CoCHRAN, ET AL, supra note 3, at 93 (recommending a "framing statement" at the conclusion of the client's narrative which should restate the important parts of the narrative and explain the next phase of the interview).

112 Interview by Attorney A with Vic, supra note 77, at 2. 
Client: Um, well, the company's name is ACT, and um, that's for Applied Computer Technologies and it is a company I started myself ten years ago, my wife and I, um, software, everybody seems to be making software now so it's a very hard market to stay in and we came up with a program that, that tracked businesses like soft drinks, beer, uh, route sales, that sort of thing [Uh, huh] and so it's an adaptable program and it customizes further to people, uh, Vicki goes out and teaches them how to use it and then I, um, change the program to their exact needs.

Attorney: And Vicki's your wife?=

Client: $\quad=$ Vicki's my wife, yes. And, uh, so those things are at an additional cost that's where we really make the profit. But, uh, we have to be selling this thing. Now, when-just before, um, Leslie and Glen both came on I wrote a new program-or actually changed the old one, to include, um, uh, bottled-water sales and raw distribution for that and so that's, uh, that's where it is at this point. and it's a great program. I mean you really have to have excellent programming to stay in business at all. So, it's a great program, and uh .. you certainly should be able to sell it. There's so many bottled-water companies starting everyday. So,

Attorney: Um, did you have a written agreement with Leslie when she came on//

Client: //Yes, it is an employment contract, uh, that, now we used an employment contract that was like a standard form and then $I$ adapted it myself.

Attorney: Do you, did you bring a copy of that?=

Client: $\quad=$ Yeah. Yes, I have a copy of that right here.

Attorney: And did you also bring a copy of the papers that were served on you? $=$

Client: $\quad=$ I did. I did. I've got those, too.

Attorney: Can you leave those with me long enough that we can get them copied and then just mail them back to you? $=$

Client: $\quad=$ No, I made a copy for you.=

Attorney: $\quad=$ Oh, that'd be great. How about the employment contract too, do you have that with you?// 
Client //Actually, that's attached.[Oh, good.] Um, I've gotta, she attached these things, um, I don't think it helps her much because I, I, made sure that I was covered. Let me see here, um, well I can't see exactly where it is right now, but I, I did write into here that, uh, employees could be dismissed at any time. [Okay] You know, without any previous notice or anything like that and so she signed that contract. So, I think we're pretty well covered there.=

Attorney: =Okay, while I have a chance to look this over then I may have some, um, follow-up questions about it so [Okay] we can talk about that later or by phone. [Okay] Um, how did you recruit her and what was her background?

Client: Well, uh, we, uh, we did some, uh, we've had salesmen that never-most of them don't stay over a year and it sort of rotated and so we decided what to do this time was to take a look for people who did know the market and so, uh, Glen had worked for Novell and, uh, he seemed to have done fairly well, so, uh, he was just looking for a smaller company so we got him away and Leslie had worked for, um, a retailer of small computers and some programming places and uh, and Xerox, uh, selling Desktop Publishing and that seemed like a pretty good background and so we thought that she should know, uh, at least something about the market and to tell you the truth they both came in everyday as the contract says. They both came in everyday, uh, to work and they, huh, they made tons of phone calls. I have phone bills. So, they were making some calls but they just weren't moving the product. It was like, uh, I don't know, the program is good, the salespeople I think are just not motivated. So, perhaps, uh, I don't know if I helped or not with the motivation of putting a cap on the salary or the advances, the loans, but, uh, that was the way to cut my cost, but, uh, maybe to get them moving cause I've had to sell this stuff myself and it just doesn't seem to be as hard as they were making it out to be and they, they talked me into offering a special and doing things like that and that just doesn't, it just doesn't work.

Attorney: Now, are Leslie and Glen related to each other? 
Client: $\quad$ No, no, um, Glen was hired about, uh, two, three months before Leslie.

Attorney: Do they, do they both have the same employment contract? $=$

Client: $\quad=$ Yes.

Attorney: Did you have any, um, uh, do you train for them, uh, when they were hired?

Client: They have to have some training on the program itself but that is very minimal, um, but, uh, I was hoping that their sales skills would be, uh, sufficient to the task.

Attorney: Did you have any discussions with um, Leslie about why the sales weren't where you thought they should be?

Client: $\quad$ Yes. We, we talked about, um, sales never matching our expectations, um, and so the, uh, when we, when we decided to put a cap on it that didn't, I don't think that came as a surprise to anyone and we did that through a set of memos, a series of memos to make sure that everybody was on line.

Attorney: Do you have copies of those?

Client: I do. They are also attached.=

Attorney: $\quad=$ Okay. Um .... what do you recall were the discussions with Leslie when you started talking about the problem of these lower sales? (09:00)

Client: Well, its been, uh, um, an ongoing thing now and I don't believe-I don't remember exactly what the conversations were but, uh, I, I made up a chart of the lower sales, um .. the, uh . . the discussionmost of the big discussion came after Leslie quit and uh, and we corresponded back and forth, uh, she, uh, claimed that, uh, well, she knew that her commission never reached, uh, what the draw was. She was paid over $\$ 11,000$ in nine months and, um, so when I-when, when, when she quit she said she wanted to be paid for the rest of the next two weeks on her draw and of course there's the draw against what? So, um, I was, uh, she wrote and I told her there was no way I was going to pay that. Uh, then she writes back and says that, uh, I'm in violation of minimum wage law. I guess uh, for her not working I need to pay some wage. Anyway, I, uh, I uh, called the Industrial Commission to check to see what my, 
uh, obligation was there and uh, and they said well you know you don't have to pay her the draw but, uh, you do need to pay her minimum wage so you don't run into trouble there. So I did send her a check for minimum wage for eighty hours for that two weeks. . . (10:41) $)^{113}$

It is useful to stop reviewing Attorney A's transcript at this point, as the same amount of time has passed as had in the transcript of Attorney B above. Simply reading these two different versions demonstrates how much more was conveyed by Vic to Attorney A because Attorney A first listened to the client's narrative and then questioned.

Note that Attorney A questioned by retracing the chronology. This may be a sensible way to combine a "time line" and "theory development questioning", when the client's initial statement of the situation contains a sufficient narrative to grasp the essential story. Notice as well that Attorney A did not announce any legal theories to his client (e.g. whether Leslie was an employee or contractor) and his inquiries did not proceed from any complicated set of legal theories. Of course, the idea that the company and salesperson may have had a contract is a legal notion, but one that an inquisitive lay person might think to ask. The topics Attorney A sought to cover are straightforward ones, many of which seek to understand the context rather than search for a particular legal defense. These include: background about the company, the contract with Leslie, getting copies of relevant papers, how Leslie was recruited, the relationship of Leslie and Glenn, training for sales people, and a discussion about a problem with sales. Reviewing such an orderly chronological inquiry should encourage beginning interviewers that they, too, could conduct a competent interview without having extensive subject matter expertise.

It is also useful to consider the various question forms effectively used in this segment of the interview. Some of these topics were broached with an open question or request:

"Will you tell me a little more about your company and what it does?"

"How did you recruit her and what was her background?"

"What do you recall were the discussions with Leslie when you

started talking about the problem of these lower sales?"114

And after each open question, the client provided a substantial narrative (50 seconds to 1 minute 45 seconds).

However, most of Attorney A's questions covering these topics were yes/ no questions. Even when Attorney A asked a yes/no question, the client provided additional relevant information on the topic selected by Attorney

113 Id. at 2-7.

114 Id. 
A. For example, although Attorney A only asked "Did you have a written agreement with Leslie?", the client not only said yes, but volunteered the very relevant information that he had "adapted" the contract himself based on a form. ${ }^{115}$ Similarly, although Attorney A only asked if the client had brought a copy of the contract, the client volunteered that there was a clause that permitted him to terminate the employee at any time so he didn't think the contract "helped" Leslie much, while at the same time he was revealing what he thought was the legal issue. This was all done in a 26 second narrative. ${ }^{116}$

The willingness of the client Vic to say more than "yes" or "no" when he had relevant information on the topic named by the lawyer is consistent with the Gricean cooperative principles that contend a conversation partner will provide truthful relevant information in the quality required for the situation. This fact about conversation should allow beginning interviewers to be relaxed in their inquiry and not worry overly much about question form. ${ }^{117}$

The open questions did usually result in longer narrations and in admissions of some face-threatening facts. For example, "How did you recruit her and what was her background?" resulted in the client sharing that few sales people had ever stayed with the company longer than a year, that the company had purposely recruited these two salespeople with experience in computer sales, and then continuing to explain that these salespeople had worked every day making "tons of phone calls" but hadn't been able to move the product. ${ }^{118}$ Similarly, the question "did you have discussions" followed by the later open question "what do you recall were the discussions" about the weak sales resulted not only in the client indicating that there were memos about the problems at the outset, but also in the client completing the story. The client admitted that after Leslie sent a demand letter, the client had sought advice from the Industrial Commission and had paid Leslie minimum wage based upon its recommendation. ${ }^{19}$

Thus, questioning in chronological order after the client's narrative and providing opportunity for the client to share additional information resulted in the client providing quite a bit of information that revealed not only what the client wanted to convey, but also what the client perhaps needed to convey regarding certain weaknesses in his case.

I 5 Id. at 3 .

116 Id. at 3-4.

117 This is not to say that the form of a question never makes any difference. All of the leading texts review the benefits of different question forms in different settings. However, it is to suggest that question form may not be the place to start with novice interviewers, but a topic to pursue once our students are comfortable in interviewing conversations.

118 Interview by Attorney A with Vic, supra note 77, at 4-5.

119 Id. at 6-7. 
During the remainder of the interview (10:47-29:08) Attorney A completed the chronology of relevant topics and followed up on some of the new information the client conveyed. ${ }^{120}$ Attorney $A$ then turned to the present and the future. Attorney $A$ asked about the Complaint and the Contract. Considering the future plans, Attorney $\mathrm{A}$ inquired about the client's goals, the impact of the suit, and the opposing party's situation and attitude. Here are the topics in order:

- Correspondence with Leslie after she left

- Replacement of Leslie after she left?

- Cost of software

- Amount of sales Leslie made

- Any other documents

- When was the Complaint served

- Complaint says company terminated employment-Tell me more

- Contract:

- Length of employment

- Terminable without any notice?

- Discussions at time Contract ended

- Discussions about weak sales

- Issues with Glen about employment

- Total damages requested in Complaint

- Client's Goals

- Profitability of Company / Impact of suit financial / reputational

- Contract-attorneys fees provision

- Contract-requirement of arbitration / mediation

- If Company complied with Contract fully

- What sort of person is Leslie

- Is she working now

- How old is Leslie? What is her financial condition?

- Atrempts to settle case

- Company's prior experience with litigation

- Relationship with Leslie

- Sort of person Leslie is

- Other documents that relate to this dispute

- Forecast you gave Leslie regarding expected sales

- Discussion regarding expected sales

- Any prior/other complaints about company from Leslie ${ }^{121}$

$120 \mathrm{Id}$. at $7-20$.

I2 I Id. at 8-20. 
It was typical that a topic might be covered by a number of questions, but the "T-funnel" structure was not used. Offering the client silent spaces to speak and coming at a topic with various questions seemed to be productive for Attorney A. A few examples will illustrate that the client shared relevant information which he thought the lawyer should know whenever the topic seemed to permit him to do so.

\begin{tabular}{|c|c|}
\hline Attorney: & $\begin{array}{l}\text { (11:08) Okay. So, have you replaced Leslie after she } \\
\text { quit? }\end{array}$ \\
\hline Client: & $\begin{array}{l}\text { No. We've been trying to go with Glen and then we } \\
\text { will, uh, Glen has just found a job, um, running a } \\
\text { store and so we do need to get a couple of sales } \\
\text { people and so we're going to do that now. [Okay] }\end{array}$ \\
\hline Client: & $\begin{array}{l}\text { But you know we increased the price of the package } \\
\text { of our computer software to cover these salespeople's } \\
\text { commission. Now it's normally } \$ 3,000 \text { and we're } \\
\text { selling it for } \$ 4,000 \text { which probably cuts into sales } \\
\text { a little bit, um, just to cover the amount of money } \\
\text { we'regiving them, uh, in hopes that they will make } \\
\text { some profit. }\end{array}$ \\
\hline Attorney: & You increased it from? \\
\hline $\begin{array}{l}\text { Client: } \\
\text {.. }\end{array}$ & $\$ 3,000$ to $\$ 4,000$ \\
\hline Attorney: & $\begin{array}{l}\text { How many, um, software packages did Leslie sell } \\
\text { while she was working for you?= }\end{array}$ \\
\hline Client: & $\begin{array}{l}=\text { Not very many. I don't have the exact number but I } \\
\text { can research that .. . Glen did sell more. }(12: 20)^{122}\end{array}$ \\
\hline
\end{tabular}

It is not clear what Attorney A was thinking when he asked if the client had replaced Leslie, but the client used this opportunity to reveal that not only had no one new been hired, but the second sales person had also left and that the price of the software had been increased from $\$ 3,000$ to $\$ 4,000$ when these two sale people came on board. This topic and sufficient silence allowed the client a face-saving way to explain some of the problem with sales without admitting to pricing the product too high. While there are certainly clients who will fail to reveal crucial information (or lie about it), raising any relevant issue and permitting the client sufficient time and space to reveal relevant information is the most important skill in questioning the client, given basic conversational norms. 
A few minutes later, after skimming the Complaint, Attorney A tests the question of how the employment ended. (The client's narrative indicated Leslie "quit.") Attorney A begins by quoting the Complaint and then interrupting and instructing the client (coded as an imperative) to say more on that issue:

\begin{tabular}{|c|c|}
\hline \multicolumn{2}{|r|}{ aterviews Cilient Vici } \\
\hline Attorney: & $\begin{array}{l}\text { Now in here she, um, says that you terminated the } \\
\text { employment agreement? }\end{array}$ \\
\hline Client: & Yes, um, according /I \\
\hline Attorney: & Tell me a little bit more about that.= \\
\hline Client: & $\begin{array}{l}\text { Yeah, well, the idea was to, um, was basically to } \\
\text { terminate the old agreement and start a new } \\
\text { agreement. So, it should have happened on exactly } \\
\text { the same day. This was the way I was going to put in } \\
\text { the cap. So, uh, I basically, uh, told Glen and Leslie } \\
\text { one day that we, uh, that was the end of that } \\
\text { employment contract and that the contract consisted } \\
\text { of this and that's when she quit. }\end{array}$ \\
\hline Attny A: & $\begin{array}{l}\text { What was the term of the existing, you know, the } \\
\text { original contract, how long was that supposed to last? }\end{array}$ \\
\hline Client: & $\begin{array}{l}\text { As long as they are employed. You know it's just } \\
\text { open-ended. }\end{array}$ \\
\hline Attny A: & $\begin{array}{l}\text { Okay. Do you remember whether it was drafted so } \\
\text { you could terminate it at any time you wanted to? }\end{array}$ \\
\hline Client: & $\begin{array}{l}\text { "Either party can terminate at any time with no } \\
\text { previous notice." = }\end{array}$ \\
\hline Attorney: & $\begin{array}{l}\text { Okay. Um, what was the discussion you had with her } \\
\text { at the time that you told her that the first agreement } \\
\text { was terminated. }\end{array}$ \\
\hline Client: & $\begin{array}{l}\text { Uh, well, I sort-of laid out that it-that this is what } \\
\text { we were going to do and uh, at that point, uh, it was } \\
\text { just a very cool reception. Uh, then the next day } \\
\text { I got the first letter from her that said, you know, she } \\
\text { doesn't, she doesn't believe this will work and so on } \\
\text { and she cleared out just like that. }(15: 20)^{123}\end{array}$ \\
\hline
\end{tabular}

The above exchange is probably the most attorney-controlled and threatening part of the interview. It also contains the closest thing to a T-funnel, where Attorney A starts asking for information on a topic ("Tell me more about" the termination of Leslie's employment) and follows with

123 Id. at 10-1 1 . 
further questions as to the contract and the conversation at the time of the employment ending.

Attorney A follows up with a question on the problems with sales, framed in favor of the client's perspective:

Attorney A Interviews Client VIC
Attorney:
(15:29) Did she ever acknowledge to you that uh,
the sales were much less than you and she thought
were going to occur?
Uh, I'm, I'm sure she was aware that it was much less
than I had hoped, uh, but of course, uh, she, Glen
and I, and Vicki all agreed that uh, that uh, sales
were down and that we needed to do something to
move forward, you know, we needed to, uh, find
better ways. So, she and Glen came up with this
special, uh, deal in the middle of the summer which,
which is not really a good idea with bottled-water
people because they're, they're very busy in the
summertime. That's their big season. Um, so that
didn't do much. We're trying things to uh, to increase
the sales. Uh, Glen actually had, uh, found, uh-
now this was nation-wide and Glen had found a
company in Chicago and he was getting things sort-
of orchestrated with them and uh, I worked with him
a little on that and now that he's quit I've taken
over. While this still hasn't paid off any profit, it, it
probably will close this month and then we'll see.
(16:32)

Again, although the question was a yes/no question, the client provided a narrative about what had been said, as well as done, by all the players to address the sales slump. This permitted the client to reveal unfavorable as well as favorable information in a face-saving way.

Attorney A covered useful topics that Attorney B never touched, including the client's goals and the client's assessment of the opposing party's circumstances and interests:

Attorney A Interviews Client VIC

Attorney: (17:21) What would you like to do about this matter if you if it could get resolved?// 
Client: //Well, I don't - to tell you the truth I'm not very inclined at this point to be very friendly. Um, she really did not do the job and now she's penalizing me for carrying her. Um, .. I don't want to pay her anything. I don't think she's done anything and she's even included in here her court-her lawyer's costs and her court costs and what have you and I don't want to pay any of that. And, if there's a way to get back some of that money that we overpaid her, if that is possible, I would, I would like to do that, you know, bring her wages more in line with her commission. (18:00)

Attorney: Okay, so the possibility of some kind of counterclaim? Client: Yeah. (18:09) $)^{125}$

This open question about the client's goals permitted the client wide latitude to present strong claims and justifications for them. This allowed Attorney A to know not only what the client's goals were, but how strongly and why the client felt as he did. Despite the client's strong assertions to not being "friendly" and wanting to bring a counterclaim, Attorney A was able to explore various issues that would relate to the possibility of settlement. Beyond asking about the company's experience with litigation and the likely impact of this litigation on the company, Attorney A asked many questions about the opposing party:

Attorney A Interviews Client VIC

Attorney: (20:50) I see correspondence she sent to you .... What kind of person is she?

Client: Uh, well, I originally thought she was going to be really dynamic. Um, she's, uh, very organized and uh .. has a very pleasant disposition but this, uh, this was very unexpected. Usually, you know, if you have a salesman and they quit that's, that's the last you hear of him. Every once in a while someone will come back and will spend a few more months with you. If they do a good job, you know, they are always welcome to stay but $=$

Attorney: =Do you know whether she's working now?

Client: $\quad$ I don't. [Okay] ... She was living in California 
actually when we hired her. She wanted to move to Utah. Uh, some personal problems she had down there so she decided she wanted to come to Utah.

Attorney: How old is she?

Client: I don't know.

Attorney: In her twenties, in her forties?

Client: I'd say she's, uh, probably in her thirries.

Attorney: Okay..... Do you know what her, uh, financial condition is?

Client At this point, no.

Attorney: Okay. . . Have you had any discussions with her at all about, um, trying to compromise the dispute and find some way to settle it? =

Client: $\quad=$ Just through the letters and she's always insisting these things and I'm trying to find ways to placate that situation. But again, I don't want to be handing out money. It's not a charity, you know, and I've given her more than she ever earned for the company.

Attorney: Um, have you ever been involved in litigation before?=

Client: $\quad=$ No. $=$

Attorney: =So this is the first experience?

Client: Yes.

Attorney: Um,//

Client $\quad / /$ I've been using that same contract for 10 years and never been sued.

...46 seconds reading documents....

Attorney: Um, do you-what is your relationship with her? How would you characterize it?

Client: $\quad$ Uh . . business. It is, she just has her distance you know. Uh, when she comes in she does her-when she came in she acted like she was doing her job. I kept to my-I do the programming and such so I'm a little isolated. Sometimes I hire programmers to help out but most of it I do myself and uh, Vicki runs the booking. The books-the utilities and what have you. She takes care of the business itself. Uh, so they're pretty much left on their own and that's the way I'd like it to work and that's the way it pretty much was with Leslie. She, she and Glen did work 
closer together, but of course, they were down the hall and doing their business.

Attorney: Is she, is she the sort of person who, uh, might be willing to, uh, compromise or is she the sort of person who would tend to be very, very angry and very punitive?

Client: I don't know. I, I, I think at this point she's got a very narrow focus and she just keeps repeating the same thing and so I don't think there's a lot of leeway there and I don't, I don't really want to compromise with her but-I know I'm right here. I, I have a good product you, you should be able to sell it and I certainly shouldn't pay for time that she was definitely out of the company. That's, that's ridiculous. So, I can't take this hit and I don't want to either. (25:07)

$\ldots 9$ seconds. ....

Attorney: One of the things that I think, um, we're going to have to do next would be to try to develop a, what I would cost, uh, call it cost/benefit/risk analysis and, um, see what this might cost in legal fees to go forward. Um, what risks of, uh, you know, an adverse result might be at trial, um, what the benefits of filing a counterclaim might be, um, um, .. that was one of the reasons why I asked you if you knew what her financial condition was because even if you were successful in getting an award against her for some sort of money damages, if she can't pay them, um, that might be [That's true.] a waste of our time and money, too. $=(26: 07)^{126}$

Here again the conversation approaches a T-funnel structure. Some of the above questions (opposing party's financial circumstances, employment status, and age) allowed Attorney A to assess whether the opposing party would be eager to settle even if she had a strong case.

The open questions (what kind of person is she) permitted the client not only to assert that Leslie was unlikely to settle, but further to assert that he felt wronged and was disinclined to settle himself. In response, Attorney A provided an explanation of why he was considering settlement from a financial/transactional, cost perspective, rather than due to any weakness in the client's case. This explanation was one of the actor-client's favorite portions of the interview, perhaps because it did suggest a resolution that

I 26 Id. at 14-18. 
was face-saving. From the attorney's perspective, this also served to prepare the client for the counseling session to come.

The attorney-controlled questioning in this interview smoothly explored the "what happened" in chronological order without threatening or confusing the client or giving the client false hope. Attorney A then turned to "what is happening now" and "what can/might/could happen in the future" to conclude his questioning. Although Attorney A certainly had legal "theories" - the contract might address the situation, maybe this case should be settled - they were not the sort of legal theories that relied upon an advanced understanding of any area of law. Attorney A modeled an interview that any novice law student should be able to conduct.

2. Attorney B.-In contrast, because Attorney B never got a client narrative or time line, there never really was a separate portion of the interview comprised of the attorney conducting "follow-up" questioning. The drama of the attorney exploring legal theories-those of the opposing party and his own-and asking questions driven by legal theories continued for an additional 26 minutes (so the interview lasted 35 minutes 36 seconds) with the client continuing to insert information she believed to be relevant. It may be that this sort of interview was what Professor Davis observed some of her students doing and what she labeled "the inquiry method" of interviewing.

The topics Attorney B chose to discuss during the remainder of the interview include (in order):

- the prayers for relief in the complaint (unpaid draw for two weeks, wages for 60 days as penalty, attorneys fees);

- how many sales Leslie needed to make to earn the draw and how many sales he made;

- the reason for Leslie leaving and confusion as to who terminated the employment relationship;

- the quality of the product;

- sales made since Leslie left;

- Glen's "big sale;"

- personnel in the company and their responsibilities;

- reason for slow sales in the summer;

- how sales people were recruited;

- experience selling product from spring through fall;

- interaction regarding the cap on draw and end of employment relationship;

- written demands and law suit claims;

- preliminary market analysis performed and possible separate 
contract for that. ${ }^{127}$

Much of the discussion was spirited and contentious, with Attorney B testing theories and the client defending and justifying actions. Again, some of the information that the client conveyed was inserted in response to marginally related questions primarily because the client appeared to think the information was important for the lawyer to have. This disjointed conveyance of information continued to the end of the interview.

It is useful to lift out certain segments of Attorney B's interview to illustrate the dynamics of this exchange. This picks up where we left off, with the client Vicki having finished her statement of the problem, including the unemployment claim.

\section{Attorney B Interviews Client VICKI}

Attorney: (9:03) But you have already paid him $\$ 750$ every two weeks you said? $\$ 10,500$ a month, that's more than minimum wage. Um, what kind of unemployment compensation is he drawing? Based on minimum wage?

Client: I'm not sure.

Attorney: I'm not sure that that's relevant at this point but we'll probably want to find out. Um, this is a complaint in which he is asking for what?

Client: $\quad$ He is asking for his attorney's fees, he's asking for us to pay a fine because we're in violation of how fast we paid him. Um,//

Attorney:

//"What of damages of gross day pay due and owing under the employment agreement for $\$ 410$ what of damages and civil penalty for failure to pay wages of and in a timely fashion."

Client: See, he doesn't//

Attorney: //Uh,//

Client: $\quad$ //just want minimum wage. He wants us to pay ... that two week draw even though he, you know he doesn't earn it. =

Attorney: [reading Complaint] =Now, actually he's talking about a penalty equal [Yes] to the wage, oh, wage rate, " of the time of separation for 60 days which will last to $\$ 1,020$ according," assuming the arithmetic's correct. Uh, "minimum wage is not 
Client:

Attorney:

Client:

Attorney: $\quad(10: 58) / / \mathrm{He}$ is, he is alleging apparently that he wants to get at least minimum wage for a period of time from the date of his termination until-or from the date, ... from the date of a, from a date certainto a date he feels he should have had payment under the terms of the contract which I will need to read clearly. Um, .. there are ... you got to get some more facts. Um, .... how much sales-okay, if he's earning a $20 \%$ commission, . . uh, how many sales would he have had to make to have earned $\$ 11,000$ ? He's got to make,

Client: Well, the program, the basic program cost $\$ 4,000$. [Okay] Okay. But, with that usually we customize it [Uh, huh] which is then//

Attorney:

Client:
//So plus some services.=

$=\mathrm{Oh}$, yeah, plus training. I go out and train, plus we usually sell a computer, [Okay] plus we usually sell, uh, several hand-held computers for the distributors. What it is, it's a-we started about ten years ago with a, a beer and soda pop distributing [Uh, huh] software for the accounting, [Uh, huh] and then my husband has updated the program for water, bottled-water distributing [Uh, huh] and that's when we decided to hire a couple of extra, well, one extra salesperson [Uh, huh] so that they can help sell it and we actually had been selling it for $\$ 3,000$ before but because we took on an extra salesperson we upped it to $\$ 4,000$. 
[Okay] But still with all the, you know the customization and the training and the computers, $/ /$

Attorney: //And then,//

Client: // you know, it can almost double.=

Attorney: $=$ Okay, so, a good sale would run somewhere $\$ 6-$ $8,000 . / 1$

Client: //Right.

Attorney: And $20 \%$ commission of that would be, what, $\$ 1200$ per sale. $=$

Client: $\quad=$ Uh, huh.=

Attorney: =Round numbers. [Uh, huh] So, he would have had to have made eleven sales.

Client: Which is only two sales a month.

Attorney: Right. And how many did he make? Has he sold any?

Client: Uh, I think he sold one or two.

Attorney: Okay. We'll need to know that, uh, because//

Client:

$/ / \mathrm{I}$ mean and we did a summer

bargain deal, you know, they talked my husband into doing, you know reducing prices//

Attorney: //discount rates for the summer?//

Client: //Right. Because the bottled-water industry is so busy that a lot of people//

Attorney: //during the summer, sure//

Client: //they don't want to venture in to this [Uh, huh] you know, new accounting program.=

Attorney: $\quad=\mathrm{Um}$, so he's made a couple of sales. We'll need to know exactly how many. How much of the $\$ 11,000$ that he drew did he actually earn? We'll need to calculate that. Uh, so we'll need to/l

Client: /No, no, no. $\$ 11,000$ is//

Attorney: //is on top of what he earned.//

Client: //Right.

Attorney: So, his draw is in excess of what he actually earned in commissions.

Client: $\quad$ Right. (14:01) 128

In this 5-minute segment of the interview Attorney B is exploring the client's theory of the case (that the employee is not entitled to draw that he didn't "earn" as commissions) by trying to get the client to calculate how much was earned with each sale and compare Leslie's sales made to the 
commissions paid. Attorney B even announces that this is something he needs to know:

"We'll need to know that, uh, because .... so he's made a couple of sales. We'll need to know exactly how many. How much of the $\$ 11,000$ that he drew did he actually earn? We'll need to calculate that." 129

But Attorney B does not "need" to know this because a salesman-employee is entitled to wages for all the hours he works even if the "commissions" never equal the wages. Unfortunately, Attorney B has not read the contract and/or doesn't know sufficient employment law to be aware of this standard. Attorney $B$ does get the information that the client knows, but has pursued this topic without actually understanding whether it is relevant.

In the course of this discussion the client Vicki also states that the company raised the price of the software from $\$ 3,000$ to $\$ 4,000$ when they hired these two sales people and that the sales people talked the company into offering a discount during the summer because summer is a slow period. These facts may be important-the $25 \%$ increase in the sales price may explain why few sales were made. Vicki may well have inserted this relevant information because it is somewhat related to the topic at hand, in keeping with the cooperative principles of conversation that are illustrated above. However, the disadvantage of the client conveying this information when the attorney is seeking a mathematical calculation is that the attorney may not have heard and may not recall it. Attorney B was asking about and focusing on the bottom line math and does not subsequently reflect or ask about the price increase.

Another topic Attorney B raises to ponder is why Leslie thought he had been terminated:

\section{Attorney B Interviews Client VICKI}

Attorney: $\quad(14: 24)$

Uh, we'll need to review carefully what it is that offended him that he took your action to mean that he was terminated. Uh, he certainly says in that paragraph you focused on, at least one good paragraph. "Termination of our employment agreement's effective on November 15th." If that is correct, uh//

Client: $\quad$ //Because my husband said at $\$ 13,000$, that's it, so he took it//

Attorney: $\quad$ /Oh, based on an expectation that, "At the rate we're paying you out, uh, advance, uh, at the rate

I 29 Id at I I-I 2. 
we're paying you your draw against future sales, November 15th is going to be the cut-off."//

Client: $\quad / /$ the deadline, that's right.

Attorney: "And either you make some sales or we're going to have to terminate this relationship."

Client: Right.

Attorney: Uh, and he then quits on October 15th in anticipation of the November 15 deadline. Is that right?//

Client: //Right.

Attorney: Um, cutting off any possibility that he could=

Client:

Attorney:

$$
\begin{aligned}
& \text { =ever make a sale } / / \\
& \qquad / / \text { make sales. ... Interesting problem. } \\
& \mathrm{Um} / /(15: 33)^{130}
\end{aligned}
$$

The client is able to explain why the company's change in the compensation was taken as a termination of their prior contractual relationship so Attorney B understands. But Attorney B's response ("interesting problem") is certainly not the empathic understanding or active listening our experts recommend ("I can see how that frustrates you").

A few turns later Attorney B continues musing about the problem from the opposing party's perspective and ignites a series of protests from the client:

\section{Attorney B Interviews Client VICKI}

Attorney: $\quad(15: 56)=I$ guess part of the question here is, if this is a written agreement, ... can one side unilaterally change the written agreement? Isn't that the question?

Client: $\quad$ Are you talking about the cap?

Attorney: Yeah. And that's-his response is to say, "I don't like that change." But his option is to say, "I don't like the change, I won't agree to it, let's talk about it some more."

Client: Alright, $=$

Attorney: =But his option, he took a different option. He took//

Client: him because we [Right] we changed the contract. $=$

Attorney: =Exactly. And, um, I suppose that in the original contract that, is there/l 
Client: $\quad$ //But, we've never paid anyone so much and received nothing in return.[Okay] You know, and when two of them together, that's twenty-two, almost $\$ 22,000$ we//

Attorney: . //At that rate you're going to go bankrupt very quickly. [Uh, huh] Um, .. it does say, "Either party," your original contract does//

Client: Attorney:

Client: Attorney: Client:

$$
\text { //termination, right.// }
$$$$
\text { //termination, "Either }
$$
party may terminate employment contract without cause and without advanced notice. Um, interesting problem as to whether he can-but he gives cause ..... He does say that it's because, "I think you've fired me."

Well, he knows we didn't fire him.//

//But he's moving a lot further.= $=$ We had no intention of firing him. We intended to motivate him and Glen, and, and Glen was doing better to get some selling done. I mean, they make hundreds of dollars worth of phone calls, you know, we know that, that neither one of them are very good salespeople and we have a good product and $=(17: 40)^{131}$

Attorney B's attempt to understand the opposing party's theory of the case produces no answers, but does motivate the client to argue the justice of her cause to the lawyer. As Attorney $B$ is expressing his understanding that Leslie "took a different option", Vicki interrupts to explain "He says we fired him because we changed the contract." 132 Attorney B continues to muse about what "the original contract" said and Vicki interrupts again to complain that the company had never paid anyone so much and received so little in return. ${ }^{133}$ This inspires Attorney B to comment that "At that rate you're going to go bankrupt very quickly"-presumably an attempt at empathy. ${ }^{134}$

Next, Attorney B tries to read the contract and the complaint where Leslie alleges being fired. Vicki protests that "he knows we didn't fire him" and continues to protest that the intention was to motive that sales force, that neither were good salesmen, and that the company has "a good

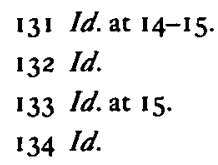


product." ${ }^{135}$ This range of protests to the attorney's attempt to understand the pleading and the contract suggests that the client may not feel that the attorney has heard and understood her situation. Indeed, Vicki's final protest appears to be an "accounting"- "a linguistic device employed whenever an action is subjected to valuative inquiry" ${ }^{136}$, including excuses, justification and scapegoating. ${ }^{137}$ The use of this device suggests Vicki is uncomfortable with this portion of the conversation exploring Leslie's theory of the case.

The client's last argument ("We have a good product") inspires Attorney B to directly explore (and question) just that issue:

\section{Attorney B Interviews Client VICKI}

Client: $\quad \ldots$ we have a good product and $=(17: 40)$

Attorney: =Let me ask a question about that. Uh, good product. Any response from the people who bought it-good, bad or indifferent?

Client: Well, we know that it's a good product because we have, you know, companies all over the nation that are using - the beer and the soda [Uh, huh] companies and so we know it's a good product cause its just been, you know, there's just been minor alterations in the software to handle bottled-water distribution.

Attorney: Okay, and, uh the people to whom you've sold this have been satisfied.//

Client: $\quad / / v e r y$ happy. Right. We sold it for about the first five [Uh, huh] years and then the next five years that we've, we've been in business, we've done, you know, up scaling and=

Attorney: =Upgrades=

Client: $\quad=$ Right. And customization and we receive annual fees and people have been very, very happy with it. So, //

Attorney: $\quad$ //Okay, um, any bottled-water companies

Client: Yes. $=$ using it?

Attorney: =So, and, and again no problems.=

Client: $\quad=$ No problems.

Attorney: So the problem is not that the product is no good it's the $=$

\footnotetext{
135 Id.

136 Cody \& McLaughlin, supra note 43, at 227.

137 Id.
} 
Client: $\quad=$ Sales, right. $=$

Attorney: =making the sales. Um, is there enough of a market?

Client: Well, we think so.=

Attorney: Okay. I, I don't know//

Client: $\quad / / I t$ 's throughout the whole country.=

Attorney: =They've had contacts with people who simply haven't been convinced to buy [Right] Leslie and, uh, Glen. Um, let me ask you have you made sales since November-since October?

Client: Well, we've got-Glen has identified this, you know, a great client in Chicago.

Attorney: And has that sold or is//

Client:

//Yes, well it's in the final=

Attorney: =It's in the final stages.

Client: $\quad$ Right.

Attorney: You're hoping.

Client: Right.

Attorney: We're all hoping. Um, next question is, um, well, are there small companies-any sales at all since October 15 th?

Client: $\quad \mathrm{Um}$, I would, I think that there are-I think my husband has also sold, [Okay] you know, because he does that too.=

Attorney: =Any of the contacts that either Glen or Leslie made?=

Client: =No. Glen, yes. Leslie, no//

Attorney: $\quad$ //The, the Chicago one. Um, will Glen

Client: get a commission on that sale in Chicago?//

Attorney: =Okay, so because he made the contact then=

Client: $\quad=$ Oh, right.

Attorney: And he has not left yet?

Client: Well, yes, he actually is now working for a-he's managing a store out in Salt Lake but he is helping us close that deal.

Attorney: All right, so he will then, by making that sale, pay you back at least part of the advance that he's got.

Client: Right. [All right] And I think he'll be able to have a little bonus on top of that.=

Attorney: =Really?

Client: Yes.=

Attorney: =It's going to be that good a deal.

Client: $\quad=$ Right. $=$

Attorney: =Terrific. At least you're still in business. That 


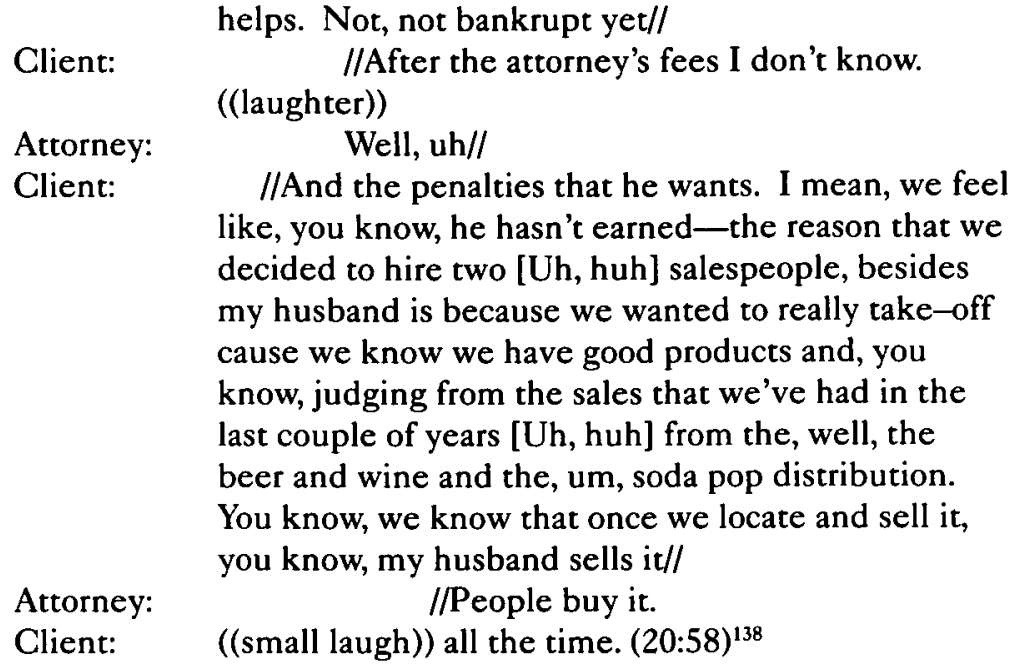

This exchange also ends in an "accounting" where the client interrupts to defend the product and explain in greater detail that the software (which had been successful with beer and soda distributors and is now adjusted for bottled water companies) should be a successful product. The use of this linguistic device suggests Vicki feels attacked or criticized. Earlier she asserts that there are bottled water companies using it, but provides no numbers and cannot name any recent sales except the one anticipated "big" one in Chicago. The client also admits that Glen has left the company (a fact she shared at 02:04 -02:23 but Attorney B did not take in) and shows some embarrassment through laughter twice. Attorney B again jokes that the company is not yet bankrupt which prompts Vicki to allude to the expense of attorneys' fees, the unfair "penalties" Leslie wants, and then to conclude with another justification of hiring two sales people and the quality of the product.

While this exchange may have helped Attorney B see the opposing party's perspective and understand weaknesses with the client's product, it is not at all clear that the discomfort caused to the client was necessary for the attorney's understanding, especially given that the attorney does not know if this information about the quality of the product is legally relevant.

Attorney $\mathrm{B}$ continued in this questioning/analyzing mode through the remainder of the interview. At one point Attorney B reads from correspondence from Leslie that refers to a "Preliminary Market Analysis" he did, and muses over what that might mean through the end of the interview. 


\section{Attorney B Interviews Client Vicki}

Attorney: (31:35) //I got you, but it says-let

me ask, let me ask you this though. Uh, what about-under his letter, next to last paragraph, last sentence, "Please let me know when I may come in to pick up my final paycheck for my work including the Preliminary Market Analysis you requested through October 14th." Tell me about that.

Client: Well, actually this is to my husband so [Right] I didn't see this til later [Okay] In fact, I never saw this letter from him until it came in the . .[Okay]

But, but, um, that's, that's why we didn't pick up, you know, his last paycheck. At that point we were sitting, we were sitting there stunned trying to figure out what he wants from us. I mean, he wanted $\$ 750$ of draw/l

Attorney: $\quad$ //But he says, but he says that he did work ourside of the contract it sounds like/l

Client: $\quad$ //including the Preliminary Market Analysis is the question//

Attorney: //Right. Is that//

Client: //That my husband requested of him I'm not sure what that is but I don't think-I think that is something within. I think he's just reminding that he has done something in the last month or whatever.=

Attorney: =Uh, do you see something-do you know of something in the contract that you have that//

Client: //that says we'll pay him more money?=

Attorney: =that says that you//

Client:

Attorney: =No, what I'm really getting at is this: beside providing him commissions on sales.. when the mar-when he does a market analysis, the Preliminary Market Analysis, [Uh, huh] is that something in addition to the regular contract?

Client: I'm not sure. I'll have to ask my husband.

Attorney: That may be something very relevant to the question of did he earn something besides the commission that he expected? [Uh, huh] Is there something in the way of what you might call, a side contract. Victor 
Client:

says to Les, "Look, um, I need, uh, a little market analysis. You've had some experience doing that. Since sales are slow why don't you spend some time doing that." [Uh, huh] Can he claim compensation for that? That may be the basis of his lawsuit. Now, under Utah law when there's an employer/employee relationship, although that might be a separate contract, and it may be a contract relationship rather than an employer/ employee//

\begin{tabular}{|c|c|}
\hline Attorney: & $\begin{array}{l}\text { another contract on him, a written one.= } \\
\text { =I understand that. But, um, if I ask you to do } \\
\text { something for me as an employee, well, any } \\
\text { employee when he leaves employment can expect to } \\
\text { get paid for work performed, uh, within a certain } \\
\text { period of time. It's spelled out in the statute-72 } \\
\text { hours I believe it is. Uh, and that's why he picks on } \\
\text { three days and says, "I wasn't paid within three days. } \\
\text { [Uh, huh] That's why I'm now filing this lawsuit } \\
\text { cause I didn't get paid within the statutorial, or } \\
\text { statutorily defined period of time when I'm entitled } \\
\text { to get paid for work that I did." So, we'll need to talk } \\
\text { to Victor to find out whether there was some } \\
\text { relationship between you and your husband or } \\
\text { between your husband and Les having to do with } \\
\text { this market analysis. That may be what he is relying } \\
\text { on// (34:50) }\end{array}$ \\
\hline $\begin{array}{l}\text { Client: } \\
\text { Attorney: }\end{array}$ & $\begin{array}{l}\text { //One of the reasons. . I don't know. } \\
\text { See, that sounds like something might be outside of } \\
\text { the contract [Uh, huh] the ordinary contract and he } \\
\text { may be able to claim wages for that. Still, uh,= }\end{array}$ \\
\hline $\begin{array}{l}\text { Client: } \\
\text { Attorney: }\end{array}$ & $\begin{array}{l}\text { =Even against the eleven thousand in draw? = } \\
=\text { That's an interesting problem. I think, I think that } \\
\text { where you've already advanced money one of the } \\
\text { questions is what did Vic say to Les? = }\end{array}$ \\
\hline & $=$ Yeah. I don't know. $=139$ \\
\hline
\end{tabular}

Here again Attorney B is trying to understand a potential weakness in the client's case-the possibility that Leslie is entitled to pay beyond what he may earn in commissions, due to work on a "market analysis." This final inquiry into the opposing party's theory of the case also seems threatening

139 ld. at 29-32. 
to the client as she interrupts frequently and protests the reasonableness of any such claim.

3. Assessment of Follow-up Questioning.-The structure that best describes Attorney B's interview is questioning driven by the attorney's desire to guess what facts might be relevant and explore legal claims that might exist. ${ }^{140}$ Attorney $\mathrm{B}$ begins by trying to guess what legal problems the client has (Unemployment? Employee or contractor? Good cause to quit? Contract terms?). Attorney B then turns to explore the client's legal theory (The company doesn't owe Leslie anything if the commissions earned are less than the "draw" paid) by trying to elicit the mathematical facts that would support that theory. Next Attorney B takes up legal theories that Leslie might conceivably have (Maybe the commissions were less than the draw because the product wasn't saleable. Maybe Leslie is entitled to some money for doing a "market analysis.")

This interview structure may feel engaging to attorney and client who are both intently focused on figuring out the problem. Indeed, the fact that Attorney B raised legal issues and law made the client feel "very confident" since it convinced Vicki that Attorney B "knew what he was talking about." ${ }^{141}$ In fact, however, most of the legal theories Attorney B explored were irrelevant. ${ }^{142}$ The opposing party was an employee and was owed wages under the contract (though they were called "draws") irrespective of whether the commissions earned were less than those wages. Thus, it was unnecessary to compute and compare the draws against commissions, unnecessary to explore a claim that the product wasn't saleable and unnecessary to consider whether the employee had done a market analysis in addition to trying to sell the product.

One must wonder whether a novice in this area of law should use his interview time asking questions driven by particular legal theories. Such an approach has not obtained the maximum amount of relevant information for Attorney B. Topics that Attorney B could have usefully explored were not touched. Attorney B never asked about the client's goals, never explored the effect of the law suit on the client company, never asked about the opposing party, never explored the feasibility of settlement-many useful topics that Attorney A did explore with a chronologically structured interview focused as much on the context of the case as the imagined underlying law.

I 40 One wonders if this approach was similar to the "inquiry method" of interviewing Professor Davis described some of her students using. See Davis, supra note 45.

I4I Ratings given by Vic and Vicki, supra note 109.

142 The one exception where Attorney B accurately alluded to a law was his final discussion regarding the "wage law" that requires payment within 72 hours of the termination of employment. Accordingly, when the client says Attorney B "knew and referred to specific .. wage laws" she was correct and Attorney B was accurate with regard to that one law. 
In fact, Vicki never told Attorney $B$ that she wanted to sue Leslie to recover some of the wages she didn't feel he had "earned" despite the fact that this goal was plainly set forth in her materials. Although Vicki felt good about Attorney B, she did not advance her company's cause as well as she might have with a quieter attorney who invited her to take control and share her goals.

Similarly, some facts that Vicki shared may not have been heard, understood and remembered by Attorney $B$, given his focus on particular questions and theories.

In teaching students how to conduct post-narrative questioning, it may be fine to encourage organized questioning of the three stages Attorney A identified-what happened to get us here, what is happening now in light of this problem (including a joint review of documents), and what solutions might one imagine. While some of Attorney A's questions related to legal theories (what does the contract say?) and other theories (has Leslie been replaced?), the fact that imagined legal theories did not drive the questioning resulted in more relevant information being shared.

The second difficulty with Attorney B's disjointed, attorney-directed, theory-driven and interruption-filled questioning is the possible negative effect on rapport. Although the actor-client Vicki rated Attorney B high ( 9 out of 10) on both "comfort" and "confidence" 143 , it is difficult to ignore her many interruptions and final speeches justifying her company's product and behavior. The dialogue suggests the client is being defensive and may feel scrutinized rather than supported. Her approval of Attorney B's interview may have more to do with how she thinks attorneys should behave and what clients should want in an attorney. Some clients may want a "mad dog" attorney on their side, and feel confident that their attorney interrupts them and makes jokes about them. Some clients may care only about the intellectual acumen of their attorney and trade empathy for an incisive analytical mind. But .... some clients will not.

This client Vicki, a female younger than the male Attorney B, did not insist on controlling the interview so that she could share quickly and in an orderly way what she had come to discuss. Instead, she was willing to go along with Attorney B's interview structure and hint at her problem until it was revealed. Some (many?) clients will insist on more control, if only to present the case in the most intelligible (if not convincing) way.

Since we will usually not know the conversational preference of our clients before the initial interview, the safer approach for understanding and creating a rapport is to accord the client substantial control over the opening stages of the interview and substantial respect in questioning throughout.

143 Ratings given by Vic and Vicki, supra note 109. 


\section{Closings}

1. Attorney B.-Just as Attorney B really permitted no client narrative, but opened with theory-driven questioning, so too does Attorney B not really conclude with anything other than the final theory-driven questioning and a quick termination of the interview. ${ }^{144}$

\section{Attorney B Interviews Client VICKI}

\section{Client: =Yeah. I don't know.=}

Attorney: =Then, we'll need to talk to Victor about that. So, there are lots of questions still to be-lots of facts yet to be gathered. Um, but an interesting problem. I've got another client that I've got to go see.

Client: $\quad$ Have you?=

Attorney: =But, um, uh, let me do a little research and you see if you can find some memos and we'll talk next week and see where we are. Would that be alright?

Client: Okay.=

Attorney: =Okay.

Client: Thank-you.

Attorney: Thank-you. (35:45) ${ }^{145}$

Attorney B imposes an ending abruptly characterizing this as "an interesting problem" and one with "lots of questions ... lots of facts yet to be gathered." This appears somewhat unsatisfying for the client as Vicki begins to ask for some conclusion ("Have you?") Attorney B promptly presents a plan of his doing "a little research" and the client looking for memos and their meeting the following week. The ending has not allowed the attorney to summarize the situation to confirm his understanding of the client's problem or goal. Attorney B appears to assume the client's goal is to defend the law suit and he has never learned that the client also wants to bring a counterclaim to recover some of the monies paid out.

2. Attomey A.-Attorney A does seize control to organize the conclusion of the interview in three ways. He asks if the client has any questions, he explains what he has planned for a later counseling session, and he invites the client to call if any questions or concerns arise. This client-friendly and organized conclusion takes less than two minutes:

I44 In fairness to Attorney B, the abrupt conclusion of the interview may have been induced by the videotaping personnel indicating that the interview had exceeded the $3^{\circ-}$ minute time limit and a second interview would soon be taking place in the room.

145 Interview by Attorney B with Vicki, supra note 78, at 32. 


Attorney Anterviews Client VIC
Attorney:
(27:52)=Okay. Um, do you have any other questions
about, uh, today, um, any other things that you feel
like we should talk about that are relevant to this?//
//No, I just thought that we should get
Client:
the thing just started and uh, want to get an idea of
how long the whole thing will take and stuff like that.
I'm sure you'll know more about that in a few days.
So that-those were my main things was to find some
way to begin to get out of this situation.
What I'd like to do would be to look this over
carefully and, um, when we get back together begin
to brainstorm about some of the things we might do
and what the cost might be and what the time frame
might be and uh, be in a better position to give you
some advice about, you know, questions you might
have, um, and then uh, you know hopefully at the
end, uh, of that you can feel comfortable about
making a decision that makes the most business
sense about what you'd like to do. [Good] Let me
give you a card and, uh, please feel free to call me
any time. Uh, I know that this sometimes can be
upsetting and, uh, don't hesitate to call if you have a
question. [Okay] And let me look this over and then
I'll have my secretary give you a call and we'll set up
another, uh, meeting to get together probably next
week.
Fantastic. [Okay] Thank-you
=Good to meet you. (29:08)

The framing for the counseling to come is excellent in keeping options open and neutral ("brainstorm about some of the things we might do and what the cost might be and what the time frame might be"); in recognizing the client will decide what to do; and in providing a standard for the client to make an informed decision ("you can feel comfortable about making a decision that makes the most business sense about what you'd like to do.")

3. Comparison.-Where Attorney B simply stopped the conversation, Attorney A provided a conclusion to their meeting and a preface for the counseling session to come. Neither lawyer knew enough about the law

146 Interview by Attorney A with Vic, supra note 77, at 19-20. 
or the facts to provide the client with an assessment of the strength of the case.

\section{E. Rapport Developing Techniques?}

How did these attorneys establish rapport with their clients? Did they employ active listening or reflection? Did they make straightforward empathic statements? Interestingly, neither attorney appeared to make any particular sort of utterance with the primary aim of developing empathy.

It is possible to identify many reflective statements of fact by Attorney B (see above). Attorney $B$ is constantly repeating what he believes he has heard the client say before asking the next question. However, I can find no statement that reflects the client Vicki's stated (or hinted) emotion. Similarly, Attorney B does not appear to employ direct empathy other than to say "good" when Vicki indicates she has brought documents. He never says "I'm sorry you have to worry about a law suit." The one time Attorney B appears to be responding to Vicki's protest ("We've never paid anyone so much and received nothing in return you know and when two of them together, that's 22 almost $\$ 22,000$ ") he makes a joke ("At that rate you're going to go bankrupt very quickly") that shows he does understand the client's concern about this money. ${ }^{147}$ Although the factual reflection may have helped the client feel heard, the absence of direct empathy and of emotional reflections raises the question of why Vicki reported such a high level of comfort and confidence (both 9 out of 10 possible). ${ }^{148}$

It would appear that Attorney B established rapport by appearing to care very much about figuring out the puzzle that Vicki presented. His frequent pursuit of legal theories and questioning about what the opposing party was claiming not only convinced Vicki that he knew the law well, but probably convinced her that he cared about her situation and solving her problem.

Attorney A presents a similar picture of employing few verbal techniques to establish rapport. Attorney A also says it is "great" that Vic brought documents. He gives three short explanatory speeches (before his questions, in explaining the cost/benefit/risk analysis that he will do, and at the conclusion of the interview) which should give the client some comfort. Attorney A similarly seemed to establish a good rapport (comfort $8 /$ confidence 7) by asking questions that the client thought were relevant ("I could tell why he asked each question"), by maintaining eye contact ("looked me in the eye-a lot-it was good"), and by imposing order and a plan (" the wage/cost/benefit analysis was a great suggestion!"). ${ }^{149}$

147 Interview by Attorney B of Vicki, supra note 78, at 15.

I 48 Ratings given by Vic and Vicki, supra note 109.

149 Id. 
This high comfort/confidence rating in the absence of any suggested verbal technique for rapport development should offer us all some comfort. ${ }^{150}$ If we truly care about the client and her problem and try to understand it, we may communicate caring and the client may feel good and trust us!

\section{Conclusion}

Using conversation analysis to study transcripts of the same interview (performed by different individuals), can suggest certain truths about lawyer-client interviews. We should incorporate these truths (and the evidence for them) when we teach interviewing. However, this study is only one study of two interviews. And even this study raised some questions about what we know (or think we know) about interviewing. Accordingly, we should use this study as a jumping off point for further inquiries.

\section{A. Lessons for Teaching}

The two goals of the initial interview-establish rapport and gather information-should be separately considered.

1. Learning Information.-With respect to gathering information, these two interviews offer strong support for our established advice to begin the interview by eliciting and listening to the client's narrative. Attorney A was able to use his time much more effectively and to learn more relevant information probably because he first obtained a short but thorough statement of the client's problem and goals simply by listening and letting the client begin the conversation. Attorney B's performance exemplified attorney-controlled, theory-driven questioning, and resulted in Attorney $B$ learning much less than did Attorney A on many important issues (the client's desire to bring a counterclaim and feelings about the justness of his cause, that the client drafted the contract from a form, facts about the opposing party, the prospect of settlement, the effect of the suit on the company), and learning almost nothing that Attorney A did not also learn.

Moreover, a careful analysis of the theories that Attorney B pursued reveals that most of the topics that were pursued (how Leslie's sales

I 50 This is not to argue that we should forget active listening and emotional reflection. I believe these techniques are most important when the lawyer is unable to feel or express genuine concern for the client or the client's claim. The first time I realized that I was consciously using this technique, ("So you feel the social workers really were unfair to you"), was when I was interviewing an abusive parent who was telling a most unsympathetic story with very off-putting behaviors. I knew that it was necessary to give some empathic response to her expressed pain, and reflecting the anger she was expressing was the first thing that occurred to me. This did recognize her as a human being with feelings and did allow her to continue with the interview. 
commissions compared to the draw paid, whether the problem was with the product or the sales force, whether Leslie was an employee or a contractor) would be shown to be legally irrelevant once the contract and the law were considered. In contrast, while Attorney A asked some questions driven by legal theory (was there an employment contract), more questions were contextual and asked in simple chronological order about the problem, and the present and future possibilities. Yet this simple approach provided useful information about the company (its experience with litigation, the harm this suit could cause, the client's relationship with and knowledge about Leslie) and about the client's attitude.

Comparing these two interviews should encourage novice interviewers who do not have substantial substantive law expertise to question by developing the story presented and asking related questions about the present and the possible future without worrying overly much about what "legal theories" to explore. It may be that a novice interviewer will properly conduct questioning somewhat differently than would an attorney experienced in the area of law presented. An attorney with subject matter expertise might well focus on topics that are typically legally relevant, beginning each topic with an open question and following up with narrow questions in the T-Funnel structure to ferret out all relevant facts. We should not expect our novice students to perform as do substantive law experts. Nevertheless, Attorney A's interview should convince us that a law student or new lawyer can make good use of a half hour interview with this questioning structure.

These two interviews both suggest that question form is not as important as is providing the client substantial opportunity to talk. Vic often gave Attorney A relevant pieces of information that related to the topic Attorney A's question rose simply because Attorney A gave Vic substantial time to speak. (For example, in response to "did you have a written agreement", Vic shared that there was an employment contract that he drafted himself from a standard form. In response to "have you replaced Leslie" Vic revealed he had not, Glen had also left, and the price of the software they had been trying to sell had been increased from $\$ 3,000$ to $\$ 4,000$ in order to cover the expected commissions.) This willingness to volunteer relevant information irrespective of question form is entirely consistent with the interview being experienced by the client as a typical conversation in which he is free to do what conversation partners typically do. Giving clients time to talk allows them to disclose even difficult facts about their situation.

Of course, Vicki also shared information that was related to the topic, irrespective of the form of Attorney B's question. The most prominent example, perhaps, was when Vicki produced the Complaint, calling it "something we received" in response to Attorney B's asking "do you have a copy of the letter", since the letter was attached to the Complaint. However, the frequency of interruptions and greater number of questions 
left Vicki much less able to volunteer everything that she needed or wanted to say. As a result, Attorney B never learned that Vicki wanted to bring a counterclaim to recover wages paid, never learned that the price of the software had been substantially increased (which might explain the poor sales), and failed to learn that Glen had left the company until the second time it was discussed. In fact, Attorney B's questioning and interrupting left Vicki little time or inclination to disclose difficult facts, but resulted instead in Vicki concluding with accountings justifying the value of her product and the justness of her cause.

A careful comparison of these two interviews provides evidence that the client-controlled narrative is a better way to begin interviews than the attorney's theory-driven questioning, from the perspective of the attorney efficiently discovering the maximum amount of relevant information. Similarly, it demonstrates that the novice attorney need not know much law (and need not pursue particular legal theories in his questioning) in order to use his half hour interview effectively, collecting additional relevant facts. Finally, there is significant benefit in treating the client as an equal conversation partner with substantial time to talk and disclose; this attitude is more significant than the question form in finding out important information.

2. Developing Rapport.-The question of how to best establish rapport is a more complicated one. It appears that people are different in conversations-some like narrative and control, others are happy to be responsive and have the professional control the conference. Accordingly, an attorney who is questioning, interrupting and controlling the interview may be accepted and even appreciated by clients who like that sort of attorney. During the interview, such an attorney (with the right client) may look smart or knowledgeable or aggressive or as someone who cares about solving the client's problem. (On the other hand, such an attorney may frustrate and confound a client who seeks control or even an equal relationship.) So, what is the attorney to do?

There are four complications to this question and this topic. First, how does that attorney know what sort of person he is interviewing? Second, how much can the attorney effectively alter his style of talk to put on a bombastic show for a client if that will impressive the particular client? Third, how much should a lawyer alter the way he is in conversation in order to impress? And finally, are there different rules for novices than there are for experts?

In answer to the first question, it is probably impossible to know at the beginning of a conference with a new client how that client likes to approach conversation and what that client is seeking in an attorney. Perhaps the attorney's preferred approach to the interview could be covered in ice breaking. Alternatively, the attorney may invite the client to set forth 
his situation and see what occurs. The client who desires control will no doubt take the floor, and the client who is more reticent may speak less and summarize more. In the later case the attorney can lead the client through the chronology with confidence, and probably gain the client's trust. I cannot imagine a rapport-building need that would require the attorney to guess the client's problem (as Attorney B tried to do) rather than to let the client define it at the outset.

Secondly, it is probably much more feasible for law students (and for attorneys) to learn about their own conversation styles and tendencies than to arbitrarily adopt unnatural styles. If a law student realizes he is happy to be quiet and let the client talk, great-good interviewing will come easily. And he can work on times and places to say things that will assert authority and control, like describing what is going to happen in the next stage of the interview. If a law student realizes she speaks quickly, tends to interrupt without realizing it, and feels the need to be in charge of the conversation, great-we can work with her to become more aware of others' styles of talk, and to let the client at least begin with a complete narrative. Whatever style comes naturally, the attorney will benefit from knowing where her natural style will work fine and when she needs to avoid the pitfalls of her natural style of talk.

Third, given evidence that the lawyering life produces disproportionate stress, ${ }^{151}$ there are important questions about when a lawyer can be her candid and sincere self and whether, for her own integrity, she should ever "put on a show" for the sole benefit of a client. Since the initial interview involves only the lawyer and client (no judge or jury to be convinced, no opposing counsel to possibly intimidate), it offers the first and best opportunity for the lawyer to be an authentic human being with a person (the client) in need. Showing concern for the client's situation should be healthy for the lawyer and adequately rapport-building for the client. If the client wishes to retain only lawyers who, on first meeting, impress by control and aggression, a healthy response by the lawyer may be to celebrate that such a client will go elsewhere.

Finally, the law student and new lawyer run certain risks that an expert lawyer does not. If the expert lawyer takes over the interview with a volley

i5 I See Susan Swaim Daicoff, Lawyer, Know Thyself: A Psychological Analysis of Personality Strengths and Weaknesses i58-59 (2004) (recounting studies showing law students and lawyers disproportionately suffer stress, depression, anxiety, alcoholism and that a change from more intrinsic (internal) motivation to more extrinsic (external) motivation accompanies that decline in mental health); Amiram Elwork, STress Management for Lawyers: How to Increase Personal \& Professional Satisfaction in the Law (3rd ed., 2007) (reporting that stressors such as time pressures, work overload, conflict, and difficult people can rob a lawyer of a satisfying career and personal life and provides concrete, clear advice about how to create a balanced and successful life in the law); Lawrence S. Krieger \& Kennon M. Sheldon, Understanding the Negative Effects of Legal Education on Laro Students: A Longitudinal Test and Extension of Self-Determination Theory, available at http://ssrn.com/abstract $=9 \mathrm{I} 3824$. 
of questions, at least most of the questions will be relevant to the sort of problem the client presents The expert controlling lawyer will not only look knowledgeable, but will actually be knowledgeable. A novice lawyer like Attorney B may impress his client with questions and statements about the law during the initial interview, but when these do not turn out to be accurate predictions of what is relevant, that attorney may lose the credibility he initially developed.

3. Balancing Information and Rapport.-Finally, the lawyer should weigh the goals and strategies for developing rapport with the goals of gathering complete and accurate information. While an experienced attorney may be more impressive to some types of clients by closely controlling the questioning from the first encounter, even that lawyer risks learning less about and from the client through this practice. While encouraging the client to control the opening descriptions of his situation may not impress the client with the attorney's knowledge or power, there will be ample opportunity to impress the client during the thorough counseling session that will follow. All the attorney needs to do during the first encounter is to impress the client enough to inspire him to return and pay the retainer!

\section{B. Lessons for Research}

The beauty of conversation analysis is that the transcribed conversation itself can demonstrate what is working and what is not. This can be studied in actual attorney-client interviews ${ }^{152}$ and with actor-clients re-enacting cases with different lawyers or law students.

Using actor-clients we are able to study different variations that arise in the same case and same attorney-client conversation. Here I have posited that actor-clients, like all people, have certain personal tendencies in conversation but that they also engage in a cooperative endeavor with the interviewing lawyers so that lawyers' conversational approaches will alter, to some extent, what the actors-client do. My next study will look at one group of actor-clients each with a few different law student interviewers to further test that proposition.

Additional studies could be designed to test what approaches enhance attorney recall. Does a client narrative followed by attorney questioning permit better recall than an interview entirely directed by attorney questioning? Does note-taking enhance recall more than it limits information? Is note-taking best during the narrative/time line or during the attorney-directed questioning? Law student interviewers could be videotaped conducting interviews with different structures and then asked to write opening memos recording all relevant information. Information

\footnotetext{
I 52 See Cunningham, supra note 20 (describing the transcription and analysis that is part of the Effective Lawyer Client Communication Project).
} 
actually spoken during the interview could be compared with information recalled and recorded in the law students' opening memos. Where law student interviewers give the client information about the law or the process, the client could be surveyed to test what the client understood and how accurately the client's understanding comports with the law student's spoken words.

The Effective Lawyer Client Communication Project intends to survey clients after the interview and compare client assessment with the content of the conversation. This project promises to add a great deal of valuable information to what we know. However, this study comparing two interviews should sound a note of warning that the client's impression at this stage may be overly influenced by the attorney's apparent expertise. It may make sense to design a study that would permit the client to comment upon her comfort and confidence in the lawyer over time as the case goes forward.

\section{Final Words}

The transcripts of these two interviews present quite a contrast. Attorney A respected the client's initial control of the conversation and allowed the client to disclose important facts in face-saving ways. Attorney A dealt so softly with Vic that Vic dubbed him "soft-spoken even mousey." In contrast Attorney B controlled the conversation with questions, interruptions and varied (mostly irrelevant) theories. Attorney B gave the client high confidence that "he knew what he was talking about." But attorneys should beware of conducting the TV-like interrogation interview. It may feel good to some clients at the time, but everything that feels good is not good for you. 